\title{
Assessment of Consumers' Motivations to Purchase a Remanufactured Product by Applying Fuzzy Delphi Method and Single Valued Neutrosophic Sets
}

\section{Amin Vafadarnikjoo, MSc}

Norwich Business School, University of East Anglia,

Norwich, NR4 7TJ, UK

E-mail: a.vafadarnikjoo@uea.ac.uk

Contact number: +44 (0) 7404573588

Nishikant Mishra, PhD (corresponding author)

Hull University Business School, University of Hull,

Hull, HU6 7RX, UK

E-mail: nishikant.mishra@hull.ac.uk

Contact number: $+44(0)$ I482 463388

Kannan Govindan, PhD

Head of SDU Centre for Sustainable Supply Chain Engineering

Institute of Technology and Innovation, University of Southern Denmark

Odense, Denmark

E-mail: kgov@iti.sdu.dk

Contact number: $+45(0) 65503188$

\section{Konstantinos Chalvatzis, PhD}

Norwich Business School, University of East Anglia,

Norwich, NR4 7TJ, UK

E-mail: k.chalvatzis@uea.ac.uk

Contact number: $+44(0) 1603597241$

(C) 2018. This manuscript version is made available under the CC-BY-NC-ND 4.0 license http://creativecommons.org/licenses/by-nc-nd/4.0/ 


\title{
Assessment of Consumers' Motivations to Purchase a Remanufactured Product by Applying Fuzzy Delphi Method and Single Valued Neutrosophic Sets
}

\begin{abstract}
Environmental issues have been worldwide matters of concern especially in the recent decade and have made many firms implement end-of-life strategies such as remanufacturing. In prior studies, the supply side of remanufacturing supply chain has been vastly brought into focus compared to the demand side. Motivational factors that encourage consumers to purchase remanufactured products are getting firms attentions in developing effective marketing strategies to assist them being more productive in the current competitive market. However, consumer acceptance of remanufactured products has been regarded as one of the main reasons why remanufacturing has remained a majorly untapped opportunity for improving supply chain productivity. This study aims at exploring the major motivational factors for buying a remanufactured bike based on the consumers' and experts' opinions. Firstly, twelve motivations identified by scrutinising the literature. Secondly, single valued trapezoidal neutrosophic numbers (SVTNN) and trapezoidal neutrosophic weighted arithmetic averaging (TNWAA) operator were employed to obtain seven significant motivations using the survey data collected from potential customers. This method is applied owing to its capability in capturing the uncertainty of consumers' subjective judgements. Thirdly, the resulted seven motivations are prioritised in accordance with the experts' judgements utilising a proposed modified fuzzy Delphi (FD) method. Ultimately, the most significant motivation to purchase a remanufactured bike identified as quality that suggests quality is the major factor affecting purchase decision of a remanufactured bike. It indicates remanufacturers should focus on quality and attempt to improve the quality of products to gain more competitive advantage. The other six factors that should be stressed by remanufacturer's marketing strategies are prioritised as warranty, price, information provision, remanufacturer's reputation, value-added services and retailer's reputation respectively.
\end{abstract}

Keywords: remanufacturing, consumer behaviour, purchase motivation, fuzzy set theory, fuzzy Delphi, neutrosophic set 


\section{Introduction}

\subsection{Remanufacturing: Definition}

Remanufacturing deals with operations bringing used products to at least their original quality and performance just like newly manufactured ones, often with exactly the same or even better warranty compared to new products (Atasu et al., 2010). Thorn and Rogerson (2002) defined a remanufactured product as one which has undertaken the process of disassembling, cleaning, inspecting, repairing, replacing and reassembling the components of a part or product to like-new condition (Hazen et al., 2012). It is also described as the ultimate form of recycling and an engine of the closed-loop supply chain (CLSC) process (Hazen et al., 2017a).

There is a number of terms used for remanufacturing (Michaud and Llerena, 2011; Thierry et al., 1995). For instance, rebuilding in automotive sector and retreading in tyre remanufacturing but the standard term utilised for the purpose of returning a used product to a like-new one is usually remanufacturing (Ayres et al., 1997; Michaud and Llerena, 2011). Other similar terms such as recycling differ from remanufacturing, since recycling converts used products into raw material which can be used in further production while remanufacturing keeps the original function of the product. It is worthwhile to differentiate between reconditioning, refurbishing, repair, reuse and repurposing. Reconditioning refers to rebuilding or repairing major components which are close to breakdown even if no clear faults have been seen in those components. Refurbishing is mainly aesthetic improvement of a product with limited improvement in functionality. Repair refers to bringing a malfunctioning or broken component back to a fit-for-use condition. Reuse denotes using a product or its components for the same motive at the end of its life cycle. Repurposing signifies using a product or its components in a way that they were not originally designed for (Chapman et al., 2010). Although the various definitions determine distinctive terminologies some of them are very close in meaning and have been used interchangeably in the literature such as Refurbishing and Remanufacturing. Recently, remanufacturing has taken on many other names such as recertified and certified pre-owned (Abbey et al., 2015).

\subsection{Remanufacturing: Benefits, Motives and Barriers}

Remanufacturing is the keystone of sustainable supply chain practices and also regarded as a substantial element of economies across Europe (Parker and Butler, 2007; Watson, 
2008). In 2015, remanufacturing industry produced around $€_{30}$ billion in turnover and recruited about 190,000 people across Europe. It is expected that by 2030, the EU remanufacturing sector could reach an annual value of $€ 70-100$ billion with the associated recruitment at approximately 450,000 to 600,000 respectively (Parker et al., 2015). Remanufacturing industry spans a broad range of products which have been remanufactured thus far including personal computers, laptops, mobile phones, cameras, mp3 players, furniture, photocopiers and toner cartridges just to name a few (Michaud and Llerena, 2011).

Buying remanufactured products is considered as a pro-environmental consumer behaviour (Jackson, 2005). Environmental issues caused by solid waste of manufactured goods have triggered worldwide concern leading to stricter environmental legislation which has made many firms implement end-of-life strategies such as remanufacturing (Michaud and Llerena, 2011). Consumers' mounting concern for environmental issues or in other words environmental awareness of consumers has presented fresh market opportunities in various businesses and might be considered as a prime motive for remanufacturing. In the US, the so-called green products constitute over $9 \%$ of the new products made available on the market (Hamilton and Zilberman, 2006; Michaud and Llerena, 2011). The same trend is confirmed based on an EU survey as approximately 8 out of $10 \mathrm{EU}$ citizens consider the environmental effect of a product as a significant criterion when deciding which product to purchase. Interestingly, $60 \%$ of interviewees regarded the environmental effect as a more significant element impacting their purchasing decisions compared to a product's brand reputation (European Commission, 2009; Michaud and Llerena, 2011). However, some studies do not confirm consumers' green motives as the main purchase driver (see Abbey et al., 2015). Jiménez-Parra et al. (2014) indicated that there is a strong consensus on the need to deeply investigate the relationship between environmental problems, in the context of supply chain (i.e. so called CLSC) with the market and consumers in the next years. Meanwhile, remanufacturing is described as the engine of CLSC processes and can act as a cornerstone of sustainable supply chain practices (Hazen et al., 2017a).

Besides its environmental merits, remanufacturing generates a myriad of opportunities for setting up many distinctly skilled jobs resulting in economic development (Parker et al., 2015). The other dimension of remanufacturing's benefits to customers may be as follows (Centre for Remanufacturing \& Reuse (CRR), 2016):

- Lower Prices; prices of remanufactured products are usually 30-40\% lower than prices of newly manufactured ones (Giutini and Gaudette, 2003) because of cost savings resulted from material recovery and product's energy content

- Availability; compared to a manufactured product, a remanufactured one may be available with a shorter lead time particularly in meeting overseas demand

- Purchasing Flexibility; remanufacturers may offer customers a variety of services providing more than just a sale such as leasing, take-back, upgrading, amortisation of capital cost and finally improvement of supplier relationships.

Figure 1 summarises an overview of benefits from remanufacturer, environment and customer viewpoints.

(C) 2018. This manuscript version is made available under the CC-BY-NC-ND 4.0 license http://creativecommons.org/licenses/by-nc-nd/4.0/ 

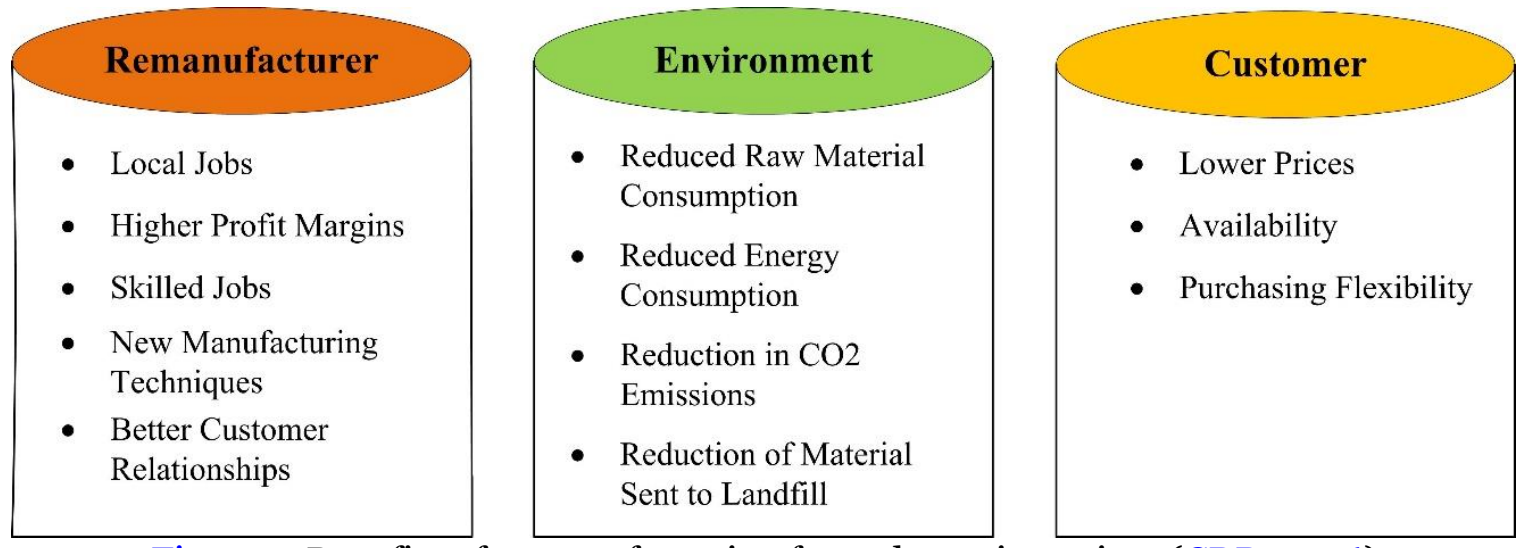

Figure 1. Benefits of remanufacturing from three viewpoints (CRR, 2016)

Even though new technologies for energy management can have significant benefits for manufacturing (Zafirakis et al., 2014). remanufactured products need only $15 \%$ of the energy used to make brand new goods (Hazen et al., 2017a; Giutini and Gaudette, 2003). Notwithstanding these virtues, remanufacturing is usually seen as an under-recognised sustainable industry. In Europe, there is a need for cross-sectional activities to make knowledge transfer easier as well as promoting the industry because unlike the recycling industry, remanufacturing lacks advancement policies throughout the Europe. Germany, the UK \& Ireland, France and Italy are four key regions in Europe estimated to account for about $70 \%$ of remanufacturing value (Parker et al., 2015). The barriers and motives for remanufacturing are depicted in Figure 2. Note that core in Figure 2 refers to a used part intended to become a remanufactured product (Parker et al., 2015).

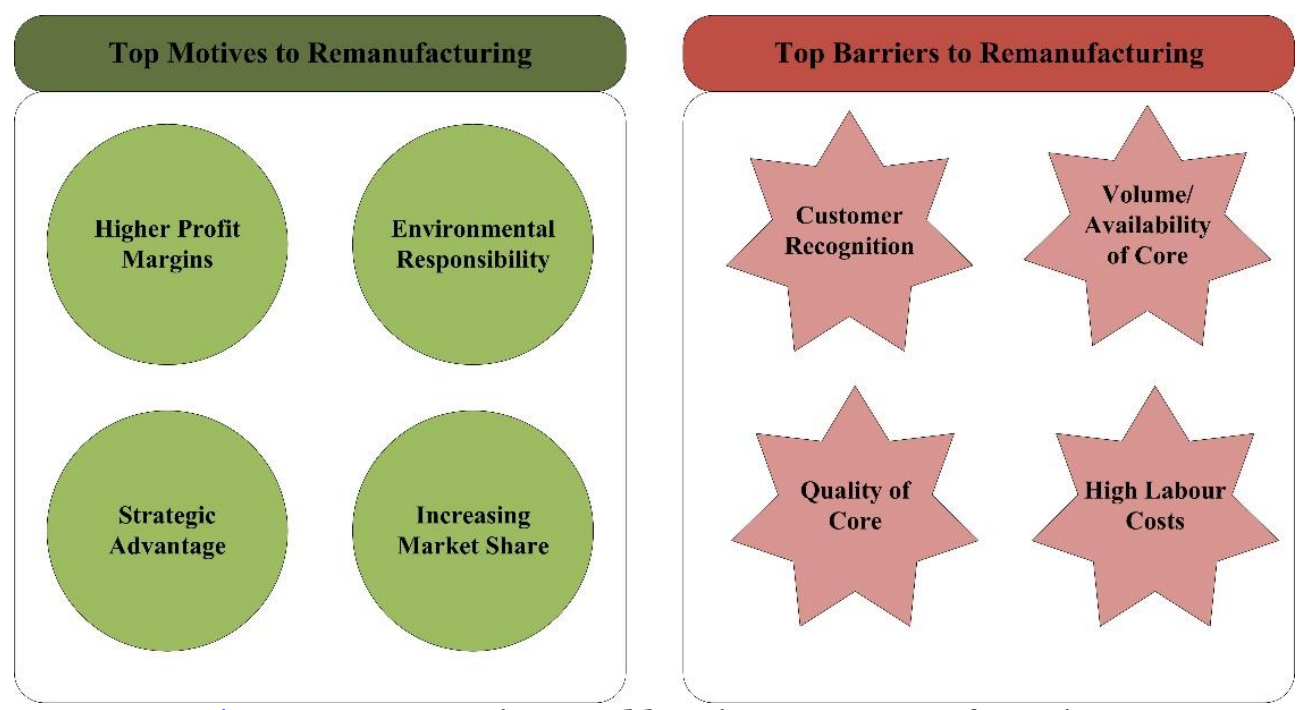

Figure 2. Top motives and barriers to remanufacturing

Managerial remanufacturing decisions need more sophisticated tools in order to make efficient remanufacturing decisions. For instance, the remanufacturing decision of one product line of Bosch tools is made only when the price market share exceeds a certain 
value otherwise remanufacturing will not be carried out (Atasu et al., 2008a; Qiang, 2015). Cannibalisation of a new product is also a cause of concern for firms even if the remanufactured product itself is profitable. Furthermore, fixed and variable costs of remanufacturing sometimes lead firms to opt out of remanufacturing their products (Ferguson and Toktay, 2006; Qiang, 2015). Moreover, original equipment manufacturers (OEMs) which offer remanufactured products usually compete with independent remanufacturers (IRs) both in sales and collection of used items for remanufacturing (Wu and $\mathrm{Wu}, 2016)$.

\subsection{Problem Description}

Consumer acceptance has been named as one of the major obstacles in adoption of remanufacturing in consumers markets (Camacho Otero et al., 2017). As also shown in Figure 2, customer recognition is regarded as one of the top barriers to remanufacturing. There has been always a misgiving about remanufacturing as a business strategy, because product managers are concerned that consumers might find remanufactured products unappealing (Abbey et al., 2015). Hazen et al. (2017a) declared consumer perception as one of the major reasons why remanufacturing has remained as a chiefly untapped opportunity to improve both supply chain sustainability and productivity. Moreover, development of the circular economy (CE) is dependent on deeper understanding of consumers' attitudes (Hazen et al., 2017b). Li et al. (2017a) indicate that success of remanufacturing process needs adoption from the supply as well as the demand ends. Although, implying the equal quality of remanufactured products and their new counterparts but consumers, remanufacturers and retailers in the CLSC do not discern such equality and accordingly tune their behaviours that must be taken into consideration (Hazen et al., 2017a; Wang et al., 2013).

Hence, investigating main motivations of consumers to purchase remanufactured products is certainly worth exploring. It helps remanufacturers recognise customer buying behaviour by paying attention to the demand end of remanufacturing supply chain. This aim would be achievable by knowing what factors actually motivate customers to purchase a remanufactured product and which ones are the most critical ones. A couple of the motivations might be price, technology, seller reputation, being environmentally friendly and so on (Jiménez-Parra et al., 2014; Subramanian and Subramanyam, 2012). The complete list of motivations is proposed later on in section 5 .

In this study, we explore the key motivations for buying a remanufactured product, specifically a bike, based on experts' and consumers' opinions in the UK. Bikes belong to machinery and automotive sector and in accordance with a 2004 study by Oakdene Hollins (Parker, 2004) the sector accounted for 11\% ( $£ 530$ million) of the total value of remanufacturing carried out in the UK and stood at the second rank after aerospace remanufacturing. In 2009, an update study in the UK revealed that combined economic value for remanufacturing and reuse in all the explored sectors was $£ 2.35$ billion (excluding aerospace industry). Moreover, the automotive sector comprises around £260 million of the total remanufacturing value standing in the second rank after ink and toner

(C) 2018. This manuscript version is made available under the CC-BY-NC-ND 4.0 license http://creativecommons.org/licenses/by-nc-nd/4.0/ 
cartridges with roughly $£ 440$ million. The other reason to choose bikes as key remanufactured products in this study was this fact that obtaining opinions of consumers of this kind of product seems more robust and reliable due to their availability and usability (Chapman et al., 2010) and as bikes are a popular transport vehicle among UK students, in our study students were regarded as the study population based in Norwich, UK.

\subsection{Methods and Contributions}

At first, single valued trapezoidal neutrosophic numbers (SVTNN) that is a generalisation of intuitionistic numbers and trapezoidal neutrosophic weighted arithmetic averaging (TNWAA) operator are employed to capture the uncertainty of consumers' subjective judgements to obtain seven motivations out of twelve initial motivations resulted from the literature survey (see section 3.1.). The seven motivations are then evaluated based on the experts' opinions utilising the Fuzzy Delphi (FD) method. The applied FD is a new methodology which is proposed by utilising harmonic, arithmetic and geometric mean methods to produce the triangular fuzzy numbers. Ultimately, taking into account both consumers' and experts' viewpoints, a combined prioritisation of motivations is proposed.

Recently, researchers particularly in various fields of applied decision making have devoted special attention to SVNSs. For instance, Ji et al. (2016), Zavadskas et al. (2016), Zavadskas et al. (2015), Ye (2015), Sahin and Yigider (2014). Generally, it is obvious that NS theory has been developing especially in the past few years and its applications span a range of different contexts such as low-carbon supplier selection (Li et al., 2017b), green product design selection (Tian et al., 2017), clay-brick selection (Chen and Ye, 2016), logistics outsourcing (Peng et al., 2016), 3PL provider selection (Ji et al., 2016), lead-zinc floatation circuit design (Zavadskas et al., 2016), construction projects selection (Ye and Smarandache, 2016), waste incineration plant site selection (Zavadskas et al., 2015) and fault diagnosis of steam turbine (Ye, 2015). However, yet there are scant practical studies in the literature while the majority of previous research focused on further theoretical advancement. Thus, in this article we aim at utilising the SVNS theory and applying SVTNN to cover a practical gap in the CLSC and remanufacturing literature.

Therefore, the contributions of this research are threefold. Firstly, it will address a shortcoming in the remanufacturing and CLSC literature by exploring the demand side of the supply chain. Main motivations of consumers that encourage the purchase of a remanufactured bike will be explored. Secondly, it proposes a developed methodological contribution in the FD method by introducing averaging viewpoint in the formation of triangular fuzzy numbers. In other words, applying arithmetic-geometric-harmonic mean inequality concept to this end. Thirdly, the SVTNN will be applied in a practical case in the remanufacturing and consumer behaviour fields. The SVTNNs are utilised in order to get the opinions of consumers owing to the strength of the theory in handling uncertainty in decision makers' (DMs') subjective judgements. 
The remaining parts of the paper are organised as follows. In section 2, the literature review is provided. In section 3, some concepts and definitions as preliminaries are presented. The research methodology is explained in section 4. In section 5, the application of the proposed methodology is elaborated and ultimately results, discussion and conclusions parts are represented in sections 6, 7 and 8 respectively. At the end of the article, two appendices A and B present the utilised consumer' opinions and experts' judgements survey to show how the data were collected.

\section{Literature Review}

Despite the continuous literature growth on remanufacturing there has been fairly few empirical studies conducted so far (Atasu et al., 2008a; Frota Neto et al., 2016; Prahinski and Kocabasoglu, 2006; Rubio et al., 2008). Hazen et al. (2012) indicated that even though remanufacturing is generally a well-studied area, researchers are left without a developed body of empirical research into addressing the topic of consumers' willingness to pay (WTP) for remanufactured products (Guide and Li, 2010; Ovchinnikov, 2011). Particularly, studies that explored the demand side of the supply chain are handful (Frota Neto et al., 2016) (see Table 1). Camacho Otero et al. (2017) performed a systematic literature review on consumer acceptance of remanufacturing and product service systems (PSS) and came up with only 24 research articles. Traditionally, there has been more attention on operational issues and product acquisition management from a supply viewpoint in the remanufacturing literature rather than on factors influencing the demand for remanufactured products from the end consumer (Ferguson and Toktay, 2006; Atasu et al., 2008b; Jimenez-Parra et al., 2012; Wang and Hazen, 2016).

\subsection{Literature on the Demand Side of the Remanufacturing}

Hazen et al. (2017a) recognised the consumers' quality perception of remanufactured goods as the sign of demand-side research significance. They declared consumer perception as one of the most important reasons for which remanufacturing has remained as a chiefly untapped opportunity to improve both supply chain sustainability and productivity and has not been successful in achieving its potential. Hazen et al. (2017b) examined consumers' intention to switch from purchasing new products to remanufactured ones by incorporating macro-level factors of price, government incentives and environmental benefits with moderating effect of micro-level consumers' attitudes. Mugge et al. (2017) explored the potential of selling refurbished smartphones using a quantitative study. They investigated what incentives are required to ameliorate acceptance of refurbished products. Alqahtani and Gupta (2017) explored the effect of offering renewing warranties on remanufactured products.

Cui et al. (2017) tried to determine a suitable remanufacturing quality strategy by proposing an integrated model based on consumer preferences over price, quality and sustainability and then considering the demand, cost and profit functions. Ma et al. (2017) explored the impact factors of consumers' purchase intention towards remanufactured electronic products. Wang and Hazen (2016) scrutinised how knowledge of 
remanufactured products in terms of green attributes, quality and cost impacts risk and value perception of consumers concerned with purchasing remanufactured products and how these perceptions subsequently influence consumers' purchase intention in China. Frota Neto et al. (2016) studied how consumers perceive remanufactured products compared to used and new ones. They studied used, remanufactured and new iPods based on a database of 1716 eBay listings to explore elements impacting price differences between them. According to their findings, price dispersal for used products is high in comparison with remanufactured products. They concluded that consumers' WTP depends in subtle ways on the nature of the product.

Agrawal et al. (2015) explored the possible impact of the remanufacturer's identity on the perceived value of new products by applying a series of behavioural experiments. Their outcomes revealed that there would be up to $8 \%$ reduction in the perceived value of new products in the presence of a remanufactured product and sold by the OEM compared to $7 \%$ increase in the perceived value of new products in the presence of third-party remanufactured products. Jiménez-Parra et al. (2014) tried to determine basic profile characteristics of potential consumers of remanufactured products. They used a questionnaire for application to potential consumers of a specific product (laptops) in two Spanish universities. Subramanian and Subramanyam (2012) investigated drivers of price differentials between new and remanufactured products utilising purchase data collected from eBay. Their analysis showed that seller reputation notably elaborates the price differentials between new and remanufactured products. Their findings indicated that products remanufactured by OEM are bought at fairly higher prices than products remanufactured by third parties. They also found that stronger warranties are not remarkably related to higher prices paid for remanufactured products. Hazen et al (2012) studied ambiguity tolerance, perceived quality and WTP for remanufactured products. They explained why consumers view remanufactured products as being of lower quality and are less willing to pay for them. They suggested that with reduction in the level of ambiguity associated with the remanufacturing processes, remanufactured products can achieve higher prices.

Table 1 represents a summary of studies on marketing of remanufactured products exploring consumer's drives and behaviours regarding remanufactured products.

Table 1. A summary of the literature focused on the demand side of remanufacturing

\begin{tabular}{lll}
\hline \multicolumn{2}{c}{ Article } & \multicolumn{1}{c}{ Characteristics } \\
\hline $\begin{array}{l}\text { Hazen } \\
2017 \mathrm{a}\end{array}$ & et al., & $\begin{array}{l}\text { Studied consumer perception of the quality of remanufactured goods and found } \\
\text { that it is a multidimensional construct on the basis of four principal factors: } \\
\text { lifespan, features, performance and serviceability }\end{array}$ \\
\hline $\begin{array}{l}\text { Abbey } \\
2017\end{array}$ & al., & $\begin{array}{l}\text { Considering consumers' concerns about the quality of remanufactured products, } \\
\text { tried to incorporate surveys and experimental studies to identify the antecedents } \\
\text { of perceived quality (in the form of perceived risk of functionality and cosmetic } \\
\text { defects) and their key influence on consumers WTP for remanufactured } \\
\text { electronics products }\end{array}$ \\
\hline $\begin{array}{l}\text { Wang et al., } \\
2016\end{array}$ & $\begin{array}{l}\text { Examined the role that information related to green attributes (energy saving, } \\
\text { material saving and emission reduction) of remanufactured products and green } \\
\text { certification play in consumer perceptions. They studied potential consumers of }\end{array}$ \\
\hline
\end{tabular}

(c) 2018. This manuscript version is made available under the CC-BY-NC-ND 4.0 license http://creativecommons.org/licenses/by-nc-nd/4.0/ 


\begin{tabular}{ll}
\hline & $\begin{array}{l}\text { remanufactured automobile parts in China by structural equation modelling } \\
\text { (SEM) }\end{array}$ \\
\hline $\begin{array}{l}\text { Khor and } \\
\text { Hazen, 2016 }\end{array}$ & $\begin{array}{l}\text { Studied how consumer attitude, subjective norms and perceived behavioural } \\
\text { control regarding buying remanufactured products influence consumer } \\
\text { intention to buy remanufactured consumer electronic products in Malaysia } \\
\text { applying theory of planned behaviour }\end{array}$ \\
\hline $\begin{array}{ll}\text { Frota Neto et } \\
\text { al., 2016 }\end{array}$ & $\begin{array}{l}\text { Studied how consumers perceive remanufactured products compared to used } \\
\text { and new ones }\end{array}$ \\
\hline $\begin{array}{l}\text { Van Weelden et } \\
\text { al., 2016 }\end{array}$ & $\begin{array}{l}\text { Based on insights from the remanufacturing literature, provided an overarching } \\
\text { understanding of the elements that impact consumer acceptance of refurbished } \\
\text { mobile phones }\end{array}$ \\
\hline $\begin{array}{l}\text { Gullstrand } \\
\text { Edbring et al., } \\
\text { 2016 }\end{array}$ & $\begin{array}{l}\text { The purpose of the research was to study consumer attitudes, motivations and } \\
\text { barriers relating to the three models with emphasis on furnishing products }\end{array}$ \\
\hline $\begin{array}{l}\text { Agrawal et al., } \\
\text { 2015 }\end{array}$ & $\begin{array}{l}\text { Explored the possible impact of the remanufacturer's identity on the perceived } \\
\text { value of new products }\end{array}$ \\
\hline $\begin{array}{l}\text { Jiménez-Parra } \\
\text { et al., 2014 }\end{array}$ & $\begin{array}{l}\text { Tried to determine basic profile characteristics of potential consumers of } \\
\text { remanufactured products }\end{array}$ \\
\hline $\begin{array}{l}\text { Subramanian } \\
\text { and }\end{array}$ & $\begin{array}{l}\text { Investigated drivers of price differentials between new and remanufactured } \\
\text { products utilising purchase data collected from eBay } \\
\text { Subramanyam, }\end{array}$ \\
$\begin{array}{ll}\text { Hazen et al., } \\
\text { 2012 }\end{array}$ & $\begin{array}{l}\text { Studied ambiguity tolerance, perceived quality and WTP for remanufactured } \\
\text { products }\end{array}$ \\
\hline $\begin{array}{l}\text { Michaud and } \\
\text { Llerena, 2011 }\end{array}$ & $\begin{array}{l}\text { Explored whether consumers are willing to pay for remanufactured products, } \\
\text { particularly when they are informed that these products are green }\end{array}$ \\
\hline
\end{tabular}

\subsection{Literature on the Supply Side of the Remanufacturing}

Table 2 summarises the literature providing insightful information on the supply side of remanufacturing dealing with the issues of remanufacturing practices or methods and product reclamation.

Table 2. A summary of the literature focused on the supply side of remanufacturing

\begin{tabular}{|c|c|}
\hline Article & Characteristics \\
\hline $\begin{array}{l}\text { Zhang et al., } \\
2017\end{array}$ & $\begin{array}{l}\text { Investigated cases in China to realise the development status of Chinese auto } \\
\text { parts remanufacturing and analyse the reverse logistics framework and related } \\
\text { issues encountered in the development of remanufacturing firms }\end{array}$ \\
\hline $\begin{array}{l}\text { Kumar et al., } \\
2017\end{array}$ & $\begin{array}{l}\text { Developed hazard rate models for core returns duration modelling, utilising data } \\
\text { from automotive industry }\end{array}$ \\
\hline $\begin{array}{l}\text { Govindan et al., } \\
\text { 2016a }\end{array}$ & $\begin{array}{l}\text { Explored formidable barriers to Indian automotive parts remanufacturing and } \\
\text { discussed significant interrelations by applying interpretive structural modelling } \\
\text { (ISM) and analytic network process (ANP) }\end{array}$ \\
\hline $\begin{array}{l}\text { Chen et al., } \\
2016\end{array}$ & $\begin{array}{l}\text { Explored remanufacturing of waste electrical and electronic equipment as well } \\
\text { as exporting part of the remanufactured products processed in bonded port } \\
\text { areas to verify profitability of remanufacturing and determine suitable } \\
\text { conditions for exporting remanufactured products to maximise profit }\end{array}$ \\
\hline
\end{tabular}

(C) 2018. This manuscript version is made available under the CC-BY-NC-ND 4.0 license http://creativecommons.org/licenses/by-nc-nd/4.0/ 10 


\begin{tabular}{|c|c|}
\hline Jia et al., 2016 & $\begin{array}{l}\text { Studied the supply-demand imbalance that is related to the management of } \\
\text { remanufacturing inventory system by focusing on a switching strategy to } \\
\text { facilitate the decision-making process }\end{array}$ \\
\hline $\begin{array}{l}\text { Mutha et al., } \\
2016\end{array}$ & $\begin{array}{l}\text { Discussed the optimal raw material acquisition strategies for a third-party } \\
\text { remanufacturer ( } 3 \mathrm{PR})\end{array}$ \\
\hline $\begin{array}{l}\text { Xiong et al., } \\
2016\end{array}$ & $\begin{array}{l}\text { Analysed the performance of manufacturer-remanufacturing and supplier- } \\
\text { remanufacturing in a decentralised CLSC, as well as desirability examination } \\
\text { from various stakeholder viewpoints. }\end{array}$ \\
\hline $\begin{array}{l}\text { Sharma et al., } \\
2016\end{array}$ & $\begin{array}{l}\text { Explored the main drivers and obstacles for remanufacturing in India. The } \\
\text { central economic, environmental and social drivers identified based on a survey. }\end{array}$ \\
\hline $\begin{array}{l}\text { Matsumoto et } \\
\text { al., } 2016\end{array}$ & $\begin{array}{l}\text { Outlined trends, inspirations and obstacles for remanufacturing and described } \\
\text { reviews of studies on selected R\&D topics in remanufacturing including } \\
\text { product design for remanufacturing, additive manufacturing for } \\
\text { remanufacturing, operations management in remanufacturing and business } \\
\text { models for remanufacturing }\end{array}$ \\
\hline $\begin{array}{l}\mathrm{Wu} \text { and } \mathrm{Wu} \text {, } \\
2016\end{array}$ & $\begin{array}{l}\text { Developed a closed-loop supply including an OEM and an IR that selling new } \\
\text { and remanufactured products. They elaborated the relation between firm's } \\
\text { decisions and remanufacturing strategies. }\end{array}$ \\
\hline Peters, 2016 & $\begin{array}{l}\text { Provided a literature review to analyse how the goal and scope definition stage- } \\
\text { the first step in the life cycle assessment (LCA) is shaped in prior LCAs for } \\
\text { remanufactured products }\end{array}$ \\
\hline Wei et al., 2015 & $\begin{array}{l}\text { Identified the motives and hurdles for remanufacturing in China. Suggestions } \\
\text { provided in accordance with the survey results to improve the remanufacturing } \\
\text { industry }\end{array}$ \\
\hline Xia et al., 2015 & $\begin{array}{l}\text { Analysed internal barriers for auto parts remanufacturing by applying grey } \\
\text { decision-making trial and evaluation laboratory (GDEMATEL) in China }\end{array}$ \\
\hline $\begin{array}{l}\text { Bulmus et al., } \\
2014\end{array}$ & $\begin{array}{l}\text { Explored the competition between an OEM and an independently operating } \\
\text { remanufacturer (IO) taking into account that OEM and IO compete not only for } \\
\text { selling their products but also for collecting cores through their acquisition } \\
\text { prices }\end{array}$ \\
\hline $\begin{array}{l}\text { Örsdemir et al., } \\
2014\end{array}$ & $\begin{array}{l}\text { Considered an OEM in competition with an IR. They elaborated how the OEM } \\
\text { competes with the IR in equilibrium. }\end{array}$ \\
\hline Pokharel and & Considered a consolidation centre that purchases used products and puts them \\
\hline Liang, 2012 & $\begin{array}{l}\text { on sale with spare parts to a remanufacturer. The decision problem is to decide } \\
\text { the acquisition price to put forward for used products and the quantities of } \\
\text { spare parts to purchase }\end{array}$ \\
\hline $\begin{array}{l}\text { Hatcher et al., } \\
2011\end{array}$ & $\begin{array}{l}\text { Provided a literature review on DfRem (Design for Remanufacture), an area } \\
\text { receiving increased attention due to the fact that product's design may have a } \\
\text { significant influence on remanufacturing efficiency }\end{array}$ \\
\hline $\begin{array}{l}\text { Ovchinnikov, } \\
2011\end{array}$ & $\begin{array}{l}\text { Investigated a firm that decides to present both new and remanufactured types } \\
\text { of its product in the market and is involved in demand cannibalization. The study } \\
\text { considered pricing and remanufacturing strategy from two viewpoints- } \\
\text { modelling and behavioural/empirical }\end{array}$ \\
\hline $\begin{array}{l}\text { Guide and } \mathrm{Li} \text {, } \\
2010\end{array}$ & $\begin{array}{l}\text { Indicated that practitioners have no reliable information to use as a guideline at } \\
\text { firms and academics have no research available to utilise as the foundation of } \\
\text { assumptions in models. They explored the cannibalization issue by applying } \\
\text { auctions to discover consumers'WTP for new and remanufactured products }\end{array}$ \\
\hline $\begin{array}{l}\text { Subramoniam } \\
\text { et al., } 2009\end{array}$ & $\begin{array}{l}\text { Formulated seven major propositions for the strategic factors in decision making } \\
\text { within remanufacturing based on literature review in the fields of }\end{array}$ \\
\hline
\end{tabular}

(C) 2018. This manuscript version is made available under the CC-BY-NC-ND 4.0 license http://creativecommons.org/licenses/by-nc-nd/4.0/ 
remanufacturing and reverse logistics as well as their experience in working with automotive remanufacturing products

\begin{tabular}{ll}
$\begin{array}{l}\text { Ijomah et al., } \\
2007\end{array}$ & $\begin{array}{l}\text { Offered the background to remanufacturing along with the findings from } \\
\text { workshops in the UK as part of research into design and manufacturing } \\
\text { perspectives to further remanufacturing }\end{array}$ \\
\hline $\begin{array}{l}\text { Debo et al., } \\
2005\end{array}$ & $\begin{array}{l}\text { Explored a problem of joint pricing and production technology selection which } \\
\text { is encountered by a manufacturer who considers introducing a } \\
\text { remanufacturable product in a market with heterogeneous consumers }\end{array}$ \\
$\begin{array}{ll}\text { Majumder and } \\
\text { Groenevelt, }\end{array}$ & $\begin{array}{l}\text { Presented a two-period model of remanufacturing in which an OEM competes } \\
\text { with a local remanufacturer under a number of reverse logistics configurations } \\
\text { for the returned items }\end{array}$ \\
\hline
\end{tabular}

As a result, based on Table 1 (demand side of the remanufacturing) and Table 2 (supply side of the remanufacturing) the following conclusions can be derived: Firstly, it is quite evident that studies involved in the exploration of the supply side of the remanufacturing have considerably outnumbered the researches dealt with the demand side of the remanufacturing. This fact is also in alignment with other studies' statements such as Camacho Otero et al. (2017), Frota Neto et al. (2016), Jimenez-Parra et al. (2012) and Wang and Hazen, (2016). Secondly, there are few studies to represent a mathematical model of uncertainty to capture the ambiguity in DMs' subjective judgements like Xia et al. (2015) where grey systems theory is applied.

\subsection{Gap Analysis and Research Highlights}

There would be a need to apply a mathematical uncertainty model to handle the vagueness in consumers' subjective judgements in the remanufacturing literature. Regarding the key importance of remanufacturing, previous research mainly focused on the supply side such as collection of end-of-life products and reverse logistics rather than demand side such as consumer profiles and marketing strategies. Generally, marketing of remanufacturing has merely been explored by a handful of academic studies. Thus, it is highly significant for firms involved in promoting the demand for remanufactured products to be aware of managing their remanufacturing and marketing activities (Jiménez-Parra et al., 2014). Accordingly, there is an absolute need from both practitioners and academics to take heed of this imbalance and try to rectify it. This study features some highlights as follows:

- One aspect of the demand side would be studying consumer buying behaviour of remanufactured products. We investigate what key motivations encourage buying a remanufactured product (a bike) based on the literature survey, experts' and consumers' opinions.

- Proposing a methodological development in the FD method. The proposed FD method can efficiently capture the opinions of experts as it can more effectively deal with a few number of DMs. 
- Applying the NS theory in a practical case in remanufacturing and consumer behaviour realm of study because of its ability in computing a large number of responses as well as properly handling ambiguity in consumers' subjective judgements.

\section{Concepts and Definitions}

\subsection{Neutrosophic Sets (NS)}

Intuitionistic fuzzy set (IFS) theory which had been already introduced by Atanassov (Atanassov, 1986) as an extension of Zadeh's fuzzy set (FS) theory (Zadeh, 1965), was generalised to a new theory called neutrosophic set theory by Smarandache in 1995 (Smarandache, 1998; Smarandache, 1999). The IFS previously had been proposed by Atanassov (Atanassov, 1986) as an extension of well-known fuzzy set theory of Zadeh (Zadeh, 1965) to surmount its weaknesses by providing non-membership degree (Govindan et al., 2015). Smarandache (Smarandache, 1998; Smarandache, 1999) introduced neutrosophic sets (NSs) which represent fuzzy information using the functions of truth, indeterminacy and falsity similar to intuitionistic fuzzy sets (IFS) with the distinction that function of indeterminacy is independent of truth and falsity functions (Ji et al., 2016). The NS theory of Smarandache generalised the IFS to provide revealing insights on a more efficient uncertainty handling of DMs subjective judgements. Nonetheless, application of NSs in practical problems is rather difficult due to the fact that values of truth, indeterminacy and falsity functions are within $] 0^{-}, 1^{+}[$( $\mathrm{Ji}$ et al., 2016; Rivieccio, 2008). As a result, single valued neutrosophic sets (SVNSs) introduced by Wang et al. (2010) in which truth, indeterminacy and falsity functions are real elements of $[0,1]$ (Ji et al., 2016). A SVTNN is also a generalisation of intuitionistic numbers.

Definition 1. (Smarandache, 1999) Let $U$ be a finite set of objects, and let $x$ signify a generic element in $U$. A NS $A$ in $U$ is characterised by a truth-membership function $T_{A}(x)$, an indeterminacy-membership function $I_{A}(x)$ and a falsity-membership function $F_{A}(x)$. $T_{A}(x), I_{A}(x)$ and $F_{A}(x)$ are the elements of $] \mathrm{o}^{-}, 1^{+}[$. It can be shown as Equation (1):

$$
A=\left\{<x,\left(T_{A}(x), I_{A}(x), F_{A}(x)\right)>: x \in U, T_{A}(x), I_{A}(x), F_{A}(x) \in\right] 0^{-}, 1^{+}[\}
$$

Note that $0^{-} \leq T_{A}(x)+I_{A}(x)+F_{A}(x) \leq 3^{+}$

\subsection{Single Valued Neutrosophic Sets (SVNS)}

As Smarandache (1999) initially introduced his theory from a philosophical viewpoint, it cannot be easily applied in practical problems. Hence, Wang et al. (2010) defined the concept of SVNS which is a subclass of NS.

Definition 2. (Wang et al., 2010) Let $U$ be a finite set of objects, and let $x$ signify a generic element in $U$. A SVNS $A$ in $U$ is characterised by a truth-membership function $T_{A}(x)$, an indeterminacy-membership function $I_{A}(x)$ and a falsity-membership function $F_{A}(x)$. $T_{A}(x), I_{A}(x)$ and $F_{A}(x)$ are the elements of $[0,1]$. It can be shown as Equation (2): 


$$
A=\left\{<x,\left(T_{A}(x), I_{A}(x), F_{A}(x)\right)>: x \in U, T_{A}(x), I_{A}(x), F_{A}(x) \in[0,1]\right\}
$$

Note that $0 \leq T_{A}(x)+I_{A}(x)+F_{A}(x) \leq 3$

\subsection{Single Valued Neutrosophic Numbers (SVNN)}

Definition 3. (Deli and Şubaş, 2014) A SVTNN $\tilde{a}=<\left(a_{1}, b_{1}, c_{1}, d_{1}\right) ; w_{\tilde{a}}, u_{\tilde{a}}, y_{\tilde{a}}>$ is a special SVNN whose $T_{\tilde{a}}(x), I_{\tilde{a}}(x)$ and $F_{\tilde{a}}(x)$ are given as Equations (3)-(5) respectively.

$$
\begin{aligned}
& T_{\tilde{a}}(x)=\left\{\begin{array}{cc}
\left(x-a_{1}\right) w_{\tilde{a}} /\left(b_{1}-a_{1}\right) & a_{1} \leq x<b_{1} \\
w_{\tilde{a}} & b_{1} \leq x \leq c_{1} \\
\left(d_{1}-x\right) w_{\tilde{a}} /\left(d_{1}-c_{1}\right) & c_{1}<x \leq d_{1} \\
\text { otherwise }
\end{array}\right. \\
& I_{\tilde{a}}(x)=\left\{\begin{array}{cc}
\left(b_{1}-x+u_{\tilde{a}}\left(x-a_{1}\right)\right) /\left(b_{1}-a_{1}\right) & a_{1} \leq x<b_{1} \\
u_{\tilde{a}} & b_{1} \leq x \leq c_{1} \\
\left(x-c_{1}+u_{\tilde{a}}\left(d_{1}-x\right)\right) /\left(d_{1}-c_{1}\right) & c_{1}<x \leq d_{1} \\
1 & \text { otherwise }
\end{array}\right. \\
& F_{\tilde{a}}(x)=\left\{\begin{array}{cc}
\left(b_{1}-x+y_{\tilde{a}}\left(x-a_{1}\right)\right) /\left(b_{1}-a_{1}\right) & a_{1} \leq x<b_{1} \\
y_{\tilde{a}} & b_{1} \leq x \leq c_{1} \\
\left(x-c_{1}+y_{\tilde{a}}\left(d_{1}-x\right)\right) /\left(d_{1}-c_{1}\right) & c_{1}<x \leq d_{1} \\
1 & \text { otherwise }
\end{array}\right.
\end{aligned}
$$

Definition 4. (Ye, 2017) Let $\tilde{a}=<\left(a_{1}, b_{1}, c_{1}, d_{1}\right) ; w_{\tilde{a}}, u_{\tilde{a}}, y_{\tilde{a}}>$ and $\tilde{b}=<$ $\left(a_{2}, b_{2}, c_{2}, d_{2}\right) ; w_{\tilde{b}}, u_{\tilde{b}}, y_{\tilde{b}}>$ be two SVTNNs and $\lambda \neq 0$ and positive then

$\tilde{a}+\tilde{b}=<\left(a_{1}+a_{2}, b_{1}+b_{2}, c_{1}+c_{2}, d_{1}+d_{2}\right) ; w_{\tilde{a}}+w_{\tilde{b}}-w_{\tilde{a}} w_{\tilde{b}}, u_{\tilde{a}} u_{\tilde{b}}, y_{\tilde{a}} y_{\tilde{b}}>$

$\tilde{a} \tilde{b}=<\left(a_{1} a_{2}, b_{1} b_{2}, c_{1} c_{2}, d_{1} d_{2}\right) ; w_{\tilde{a}} w_{\tilde{b}}, u_{\tilde{a}}+u_{\tilde{b}}-u_{\tilde{a}} u_{\tilde{b}}, y_{\tilde{a}}+y_{\tilde{b}}-y_{\tilde{a}} y_{\tilde{b}}>$

$\lambda \tilde{a}=<\left(\lambda a_{1}, \lambda b_{1}, \lambda c_{1}, \lambda d_{1}\right) ; 1-\left(1-w_{\tilde{a}}\right)^{\lambda}, u_{\tilde{a}}^{\lambda}, y_{\tilde{a}}^{\lambda}>$

$\tilde{a}^{\lambda}=<\left(a_{1}^{\lambda}, b_{1}^{\lambda}, c_{1}^{\lambda}, d_{1}^{\lambda}\right) ; w_{\tilde{a}}^{\lambda}, 1-\left(1-u_{\tilde{a}}\right)^{\lambda}, 1-\left(1-y_{\tilde{a}}\right)^{\lambda}>$

Definition 5. (Ye, 2017) Let $\tilde{a}=<(a, b, c, d) ; w_{\tilde{a}}, u_{\tilde{a}}, y_{\tilde{a}}>$ be a SVTNN. Then the score function of $\tilde{a}$ can be calculated in accordance to Equation (10):

$S(\tilde{a})=\frac{1}{12}(a+b+c+d)\left(2+w_{\tilde{a}}-u_{\tilde{a}}-y_{\tilde{a}}\right) \quad S(\tilde{a}) \in[0,1]$

Definition 6. (Ye, 2017) In order to compare two SVTNNs $\tilde{a}=<$ $\left(a_{1}, b_{1}, c_{1}, d_{1}\right) ; w_{\tilde{a}}, u_{\tilde{a}}, y_{\tilde{a}}>$ and $\tilde{b}=<\left(a_{2}, b_{2}, c_{2}, d_{2}\right) ; w_{\tilde{b}}, u_{\tilde{b}}, y_{\tilde{b}}>$ according to Equation (10), the score functions will be computed if $S(\tilde{a})>S(\tilde{b})$ then $\tilde{a}>\tilde{b}$; if $S(\tilde{a})=S(\tilde{b})$ then $\tilde{a}=\tilde{b}$.

\subsection{Fuzzy Set theory}

(C) 2018. This manuscript version is made available under the CC-BY-NC-ND 4.0 license http://creativecommons.org/licenses/by-nc-nd/4.0/ 
FS theory proposed by Zadeh (1965) is a useful tool to deal with vagueness of human's subjective judgements (Lai and Hwang, 1995; Vafadarnikjoo et al., 2015). This theory has been widely applied in a broad range of fields such as engineering, management and business and has differences with other non-deterministic theories such as probability statistics and grey systems theory (Govindan et al., 2016b).

Definition 7. A fuzzy number is a special fuzzy set $F=\left\{\left(x, \mu_{F}(x)\right), x \in R\right\}$ where $x$ takes its values from real numbers; $R:-\infty<x<+\infty$ and $\mu_{F}(x)$ is a continuous mapping from $R$ to the closed interval $[0,1]$ (Kwong and Bai, 2002). A triplet $(l, m, r)$ where $l \leq m \leq r$ denotes a triangular fuzzy number (TFN). Each value of $l, m$ and $r$ represents the lowest, medium and greatest possible value respectively which defines a fuzzy occurrence. The membership function of a TFN is defined as Equation (11) (Vafadarnikjoo et al., 2015):

$f_{A}(x)=\left\{\begin{array}{cc}0 & x<l \\ \frac{x-l}{m-l} & l \leq x \leq m \\ \frac{r-x}{r-m} & m \leq x \leq r \\ 0 & x>r\end{array}\right.$

Definition 8. Let $\tilde{A}=\left(a_{1}, a_{2}, a_{3}\right)$ and $\tilde{B}=\left(b_{1}, b_{2}, b_{3}\right)$ be two TFNs. Then the four basic arithmetic operations are as Equations (12)-(15) (Lee, 2005; Vafadarnikjoo et al., 2015; Vafadarnikjoo, 2014):

$\tilde{A}-\tilde{B}=\left(a_{1}, a_{2}, a_{3}\right)-\left(b_{1}, b_{2}, b_{3}\right)=\left(a_{1}-b_{3}, a_{2}-b_{2}, a_{3}-b_{1}\right)$

$\tilde{A}+\tilde{B}=\left(a_{1}, a_{2}, a_{3}\right)+\left(b_{1}, b_{2}, b_{3}\right)=\left(a_{1}+b_{1}, a_{2}+b_{2}, a_{3}+b_{3}\right)$

$\tilde{A} \times \tilde{B}=\left(a_{1}, a_{2}, a_{3}\right) \times\left(b_{1}, b_{2}, b_{3}\right) \approx\left(a_{1} b_{1}, a_{2} b_{2}, a_{3} b_{3}\right)$

$\tilde{A} \div \tilde{B}=\left(a_{1}, a_{2}, a_{3}\right) \div\left(b_{1}, b_{2}, b_{3}\right) \approx\left(a_{1} / b_{3}, a_{2} / b_{2}, a_{3} / b_{1}\right)$

\section{Methodology}

Our research question is what are the key motivations for potential consumers to buy a remanufactured product like a bike? In our study, university students based in Norwich, UK are regarded as the study population. Bikes are considered because they are a popular transport vehicle among university students and as previously explained they belong to machinery and automotive sector which is accounted for $11 \%$ ( $£ 530$ million) of the total value of remanufacturing carried out in the UK. The overall view of research steps that are taken to answer our research question are shown in Figure 3 and are further discussed in the application part of the paper (section 5).

Based on the literature review, there would be a need to apply a mathematical uncertainty model to handle the vagueness in DMs' (consumers/experts) subjective judgements like SVNS and FS theories. In our study, consumers and experts are regarded as DMs in the second phase of the research where SVNS theory and FD method have been utilised 
respectively. We take advantage of the trapezoidal neutrosophic weighted arithmetic averaging (TNWAA) operator which is a SVTNNs aggregation method in obtaining the consumers' opinions through capturing their judgement's uncertainty. SVNS has been applied in this study as a more powerful tool compared to FS and IFS theories to deal with consumers' subjective judgement. The TNWAA is utilised in the second step to deal with consumers' opinions because it can provide the advantages of SVNS theory along with the ability to involve a large number of responses. The FS theory was applied in the FD method in which it is improved by using harmonic, arithmetic, and geometric mean method in making the triangular fuzzy numbers. The proposed FD method can efficiently capture the opinions of DMs (i.e. experts) in order to assess the obtained results from consumers' opinions in the previous step. The reason for applying FD in this step is that it can more effectively deal with our size of DM sample i.e. eight experts. In sections 4.1. and 4.2. the TNWAA operator and the proposed FD method are explained. In the final step, regarding the viewpoints of both experts' and consumers' opinions, a combined prioritisation of motivations is provided.

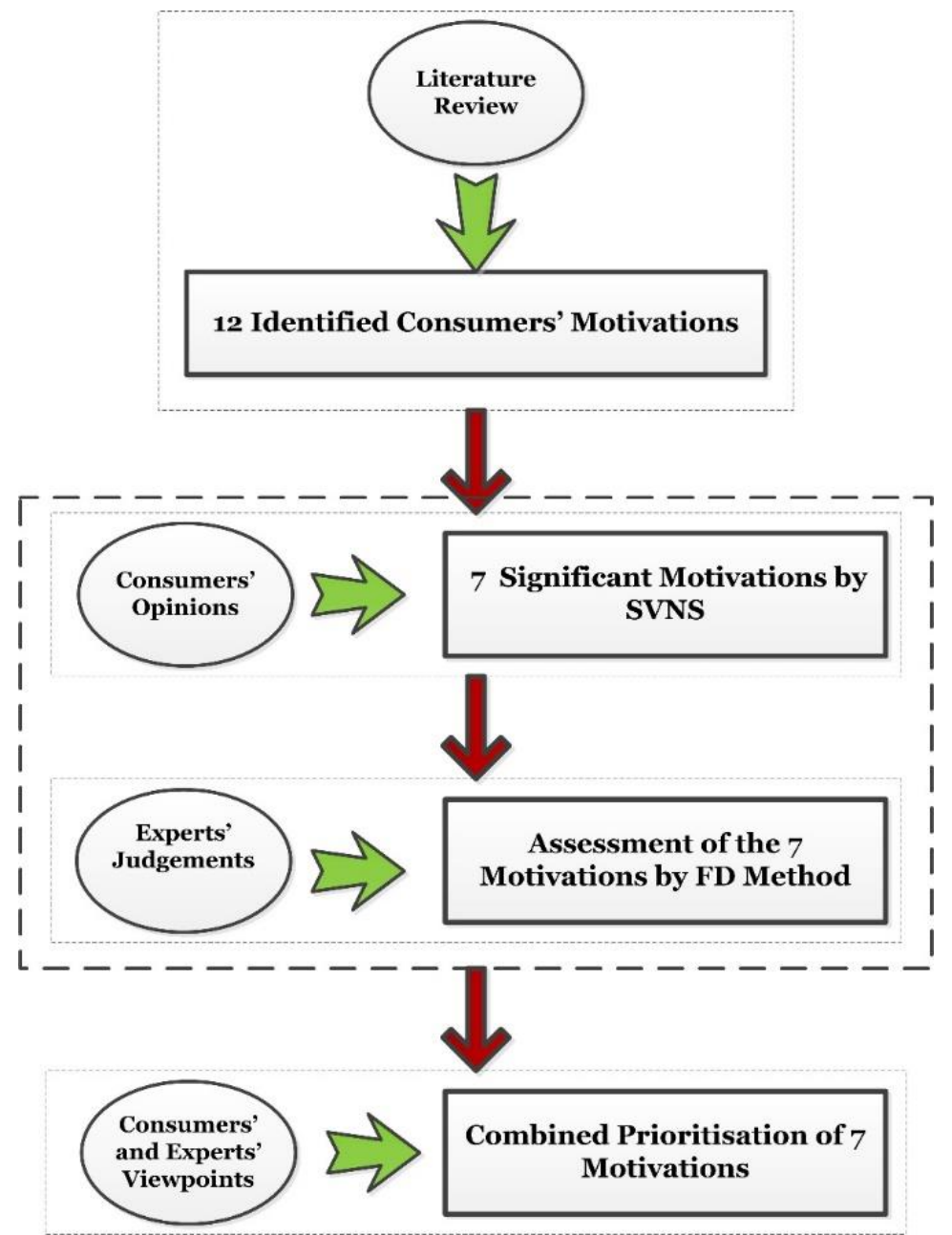

Figure 3. Overall view of research steps 


\subsection{TNWAA Operator}

Theorem 1. (Ye, 2017) Let $\tilde{a}_{j}=<\left(a_{j}, b_{j}, c_{j}, d_{j}\right) ; w_{\tilde{a}_{j}}, u_{\tilde{a}_{j}}, y_{\tilde{a}_{j}}>\quad(j=1,2, \ldots, n)$ be a set of SVTNNs, then a TNWAA operator is calculated based on Equation (16):

$\operatorname{TNWAA}\left(\tilde{a}_{1}, \tilde{a}_{2}, \ldots, \tilde{a}_{n}\right)=\sum_{j=1}^{n} p_{j} \tilde{a}_{j}=<\left(\sum_{j=1}^{n} p_{j} a_{j}, \sum_{j=1}^{n} p_{j} b_{j}, \sum_{j=1}^{n} p_{j} c_{j}, \sum_{j=1}^{n} p_{j} d_{j}\right) ; 1-$ $\prod_{j=1}^{n}\left(1-w_{\tilde{a}_{j}}\right)^{p_{j}}, \prod_{j=1}^{n} u_{\tilde{a}_{j}}^{p_{j}}, \prod_{j=1}^{n} y_{\tilde{a}_{j}}^{p_{j}}>$

Where $p_{j}$ is the weight of $\tilde{a}_{j}(j=1,2, \ldots, n)$ in a way that $p_{j}>0$ and $\sum_{j=1}^{n} p_{j}=1$. When, $p_{j}=\frac{1}{n}$ for $j=1,2, \ldots, n$ then the TNWAA will be converted to TNAA.

The proof of theorem 1 utilising mathematical induction is available in Ye (2017).

\subsection{FD Method}

Step 1: Pair-wise Comparison Matrix

The experts are asked to evaluate elements on the basis of their significance and relative importance of each element $C_{i}$ over $C_{j}$ using the Saaty importance scale (Table 3 ).

Table 3. Importance rating scale (Saaty, 1980)

\begin{tabular}{cc}
\hline Numerical Scale & Verbal Scale \\
\hline 1 & Equal Importance \\
2 & Weak Importance \\
3 & Moderate Importance \\
4 & Moderate Plus Importance \\
5 & Strong Importance \\
6 & Strong Plus Importance \\
7 & Very Strong Importance \\
8 & Very Very Strong Importance \\
9 & Extreme Importance \\
\hline
\end{tabular}

Given $C_{1}, C_{2}, \ldots, C_{n}$ represent a collection of elements, while $a_{i j k}$ denotes a quantified judgement on a pair of elements, $C_{i}$ and $C_{j}$ by expert $k(k=1,2, \ldots, m)$. This results in a pair-wise comparison matrix as shown in Equation (17) (Hayaty et al., 2014; Liu and Chen, 2007):

$A_{k}=\left[a_{i j k}\right]=\left[\begin{array}{cccc}1 & a_{12 k} & \cdots & a_{1 n k} \\ 1 / a_{12 k} & 1 & \cdots & a_{2 n k} \\ \vdots & \vdots & \ddots & \vdots \\ 1 / a_{1 n k} & 1 / a_{2 n k} & \cdots & 1\end{array}\right]$

Step 2: Consistency Calculation

(C) 2018. This manuscript version is made available under the CC-BY-NC-ND 4.0 license http://creativecommons.org/licenses/by-nc-nd/4.0/ 
Based on Saaty's suggestion (Saaty, 1980) a consistency test should be carried out to differentiate the consistent comparisons (with acceptable deviations) from the inconsistent comparisons (with unacceptable deviations). The consistency test includes the use of a consistency ratio (CR) (Equation (18)) where random (consistency) index (RI) depends on the number of elements being evaluated (n) (Table 4) and $\lambda_{\max }$ is the maximum value of the eigenvector. If the value $C R \geq 0.1$ (a threshold of 10\%) then the expert has to undergo a revision and redo the pair-wise comparisons (Leung and Cao, 2000). The consistency issue in the pair-wise comparison matrix has been considered extensively in the literature (Aguarón et al., 2016; Linares et al., 2016; Pereira and Costa, 2015; Ishizaka and Lusti, 2004). Saaty (1994) recommended thresholds of $5 \%$ and $8 \%$ for 3 by 3 and 4 by 4 matrices, respectively (Aguaron and Moreno-Jiménez, 2003).

$$
C R=\frac{\left(\lambda_{\max }-n\right)}{(n-1)} / R I
$$

Table 4. Random (consistency) index (RI) (Golden et al., 1989)

\begin{tabular}{ccccccccccc}
\hline $\mathrm{n}$ & 1 & 2 & 3 & 4 & 5 & 6 & 7 & 8 & 9 & 10 \\
\hline $\mathrm{RI}$ & $\mathrm{O}$ & $\mathrm{O}$ & 0.58 & 0.9 & 1.12 & 1.24 & 1.32 & 1.41 & 1.45 & 1.49 \\
\hline
\end{tabular}

\section{Step 3: Fuzzy pair-wise comparison matrix}

In order to construct the fuzzy pair-wise comparison matrix, all opinions of $m$ experts on the judgement of each pair of elements should be incorporated as a TFN (Equation 19) which is constructed based on Equations (20)-(22):

$\tilde{a}_{i j}=\left(\alpha_{i j}, \delta_{i j}, \gamma_{i j}\right)$

$\alpha_{i j}=\frac{m}{\sum_{k=1}^{m} \frac{1}{a_{i j k}}}$

$\delta_{i j}=\sqrt[m]{\prod_{k=1}^{m} a_{i j k}}$

$\gamma_{i j}=\frac{1}{m} \sum_{k=1}^{m} a_{i j k}$

Where $\alpha_{i j}, \delta_{i j}$ and $\gamma_{i j}$ are calculated on the basis of the harmonic- $\mathrm{H}(\mathrm{f})$, geometric- G(f) and arithmetic- $\mathrm{A}(\mathrm{f})$ mean respectively. It is well-known that $A(f) \geq G(f) \geq H(f)$ and called the arithmetic-geometric-harmonic mean inequality (Xia et al., 1999). Thus, $\alpha_{i j} \leq$ $\delta_{i j} \leq \gamma_{i j}$ is obtained and suitable to be applied in a TFN. Following the above outlines, a fuzzy reciprocal pair-wise comparison matrix can be computed as shown in Equation (23):

$$
\tilde{A}=\left[\tilde{a}_{i j}\right]=\left[\begin{array}{cccc}
(1,1,1) & \left(\alpha_{1 j}, \delta_{1 j}, \gamma_{1 j}\right) & \cdots & \left(\alpha_{1 n}, \delta_{1 n}, \gamma_{1 n}\right) \\
\left(\frac{1}{\gamma_{1 j}}, \frac{1}{\delta_{1 j}}, \frac{1}{\alpha_{1 j}}\right) & (1,1,1) & \cdots & \left(\alpha_{2 n}, \delta_{2 n}, \gamma_{2 n}\right) \\
\vdots & \vdots & \ddots & \vdots \\
\left(\frac{1}{\gamma_{1 n}}, \frac{1}{\delta_{1 n}}, \frac{1}{\alpha_{1 n}}\right) & \left(\frac{1}{\gamma_{2 n}}, \frac{1}{\delta_{2 n}}, \frac{1}{\alpha_{2 n}}\right) & \cdots & (1,1,1)
\end{array}\right]
$$


Step 4: Fuzzy weights calculation

Fuzzy weight of each element (i.e. $\widetilde{W}_{i}$ ) can be calculated using Equations (24) and (25):

$\tilde{Z}_{i}=\left(\sum_{j=1}^{n} \tilde{a}_{i j}\right) / n \quad \forall i=1,2, \ldots, n$

$\widetilde{W}_{i}=\tilde{Z}_{i} /\left(\sum_{i=1}^{n} \tilde{Z}_{i}\right) \quad \forall i=1,2, \ldots, n$

Step 5: Weights defuzzification

Convert fuzzy weights into crisp values by utilising Equation (26) (Bhosale and Kant, 2016) to obtain best non-fuzzy performance (BNP) so as to rank the elements using the order relation of crisp numbers which are real numbers.

$B N P=\frac{[(r-l)+(m-l)]}{3}+l$

\section{Application Case}

\subsection{Identification of consumers' motivations}

Through review of the related literature in consumer behaviour and remanufacturing as discussed in the literature review section, twelve main consumers' motivations which lead potential consumers to purchase a remanufactured product (in our study a remanufactured bike) were identified (Table 5).

Table 5. Identified consumers' motivations

\begin{tabular}{|c|c|c|}
\hline Motivation & Definition & Reference \\
\hline $\begin{array}{c}\text { Environmental } \\
\text { Impact }\end{array}$ & $\begin{array}{l}\text { A remanufactured bike may have reduced } \\
\text { impact on the environment }\end{array}$ & $\begin{array}{l}\text { Jiménez-Parra et al., } \\
2014\end{array}$ \\
\hline $\begin{array}{l}\text { Information } \\
\text { Provision }\end{array}$ & $\begin{array}{l}\text { Information about a remanufactured } \\
\text { bike's status includes information like its } \\
\text { age, possible damages, proportion of } \\
\text { remanufactured components and results } \\
\text { of performance tests. Also, information } \\
\text { about the use history could give insight on } \\
\text { how the bike was used for example use } \\
\text { intensity (average hours per day), reason } \\
\text { of discarding }\end{array}$ & $\begin{array}{l}\text { Van Weelden et al., } \\
2016\end{array}$ \\
\hline $\begin{array}{l}\text { OEM's Brand } \\
\text { Reputation }\end{array}$ & $\begin{array}{l}\text { A well-recognised OEM's brand may } \\
\text { encourage the purchase of a } \\
\text { remanufactured bike of that OEM's brand }\end{array}$ & $\begin{array}{l}\text { Michaud and Llerena, } \\
2011\end{array}$ \\
\hline Price & $\begin{array}{l}\text { Lower price of a remanufactured bike in } \\
\text { comparison to a similar new bike }\end{array}$ & $\begin{array}{l}\text { Jiménez-Parra et al., } \\
2014\end{array}$ \\
\hline
\end{tabular}

(C) 2018. This manuscript version is made available under the CC-BY-NC-ND 4.0 license http://creativecommons.org/licenses/by-nc-nd/4.0/ 


\begin{tabular}{|c|c|c|}
\hline Quality & $\begin{array}{l}\text { Quality factors such as Performance } \\
\text { Characteristics and Perceived Functional } \\
\text { Risk }\end{array}$ & $\begin{array}{l}\text { Gullstrand Edbring et } \\
\text { al., 2016; Hazen et al., } \\
\text { 2017a }\end{array}$ \\
\hline $\begin{array}{l}\text { Remanufacturer's } \\
\text { Reputation }\end{array}$ & An approved remanufacturer by the OEM & $\begin{array}{l}\text { Michaud and Llerena, } \\
2011\end{array}$ \\
\hline $\begin{array}{l}\text { Retailer's } \\
\text { Reputation }\end{array}$ & $\begin{array}{l}\text { Shops'/retailers' reputation or ease of } \\
\text { access. Bikes being available in a popular } \\
\text { established retail channel or if available in } \\
\text { special stores; being conveniently } \\
\text { accessible for potential customers }\end{array}$ & $\begin{array}{l}\text { Van Weelden et al., } \\
2016\end{array}$ \\
\hline Scarcity & $\begin{array}{l}\text { Scarcity or non-availability of new specific } \\
\text { bikes means they are not available in } \\
\text { shops/retailers or markets because they } \\
\text { are no longer produced thus, they may } \\
\text { motivate consumers to purchase } \\
\text { remanufactured counterparts }\end{array}$ & $\begin{array}{l}\text { Gullstrand Edbring et } \\
\text { al., } 2016\end{array}$ \\
\hline Technology & $\begin{array}{l}\text { Remanufactured bikes that incorporate } \\
\text { the latest technology }\end{array}$ & $\begin{array}{l}\text { Jiménez-Parra et al., } \\
2014\end{array}$ \\
\hline Unique Design & $\begin{array}{l}\text { Design and appearance of } \\
\text { remanufactured bike may work as a } \\
\text { motivator }\end{array}$ & $\begin{array}{l}\text { Gullstrand Edbring et } \\
\text { al., } 2016\end{array}$ \\
\hline $\begin{array}{l}\text { Value-added } \\
\text { Services }\end{array}$ & $\begin{array}{l}\text { Giving a trying out chance to consumer } \\
\text { before a buying is done; free shipping, } \\
\text { reward levels (for instance having a Hall of } \\
\text { Fame for customers) and so on may } \\
\text { motivate consumers to purchase a } \\
\text { remanufactured bike }\end{array}$ & Frota Neto et al., 2016 \\
\hline Warranty & $\begin{array}{l}\text { Providing appropriate warranty may } \\
\text { motivate consumers to purchase a } \\
\text { remanufactured bike }\end{array}$ & $\begin{array}{l}\text { Frota Neto et al., 2016; } \\
\text { Subramanian and } \\
\text { Subramanyam, 2012 }\end{array}$ \\
\hline
\end{tabular}

\subsection{Acquiring consumers' opinions}

The SVTNNs as defined in Definition 3 were utilised to capture the vagueness of consumers' subjective judgements to find out which elements described in Table 5 are more significant according to consumers' viewpoints. Each participant was asked to give their opinion based on a 7-point scale (1-7) represented in Table 6. For this purpose, a couple of questionnaires (Appendix A) in on-line and print formats were handed out on a random basis among student participants. The participants in our survey were university students based in UK mainly at the University of East Anglia, Norwich, UK. University students were contacted by email to fill out the on-line questionnaire and for some of them the questionnaire forms were printed out to be filled in. Among responses, 104 ones were complete and suitable for further analysis. The descriptive statistics of the 104 students who participated in the first phase of this research indicates that $52.88 \%$ (55 students) were at undergraduate level and $47.12 \%$ (49 students) were at postgraduate level either master's degree or PhD students. 
Table 6. Linguistic values of SVTNNs for the linguistic terms (Ye, 2017)

\begin{tabular}{ccc}
\hline $\begin{array}{c}\text { Numerical } \\
\text { Scale }\end{array}$ & Verbal Scale & SVTNNs \\
\hline 1 & Very Unimportant (VU) & $<(0.1,0.1,0.1,0.1) ; 0.5,0.3,0.3>$ \\
2 & Unimportant (U) & $<(0.2,0.3,0.4,0.5) ; 0.6,0.2,0.2>$ \\
3 & Fairly Unimportant (FU) & $<(0.3,0.4,0.5,0.6) ; 0.7,0.1,0.1>$ \\
4 & Medium (M) & $<(0.4,0.5,0.6,0.7) ; 0.8,0.0,0.1>$ \\
5 & Fairly Important (FI) & $<(0.5,0.6,0.7,0.8) ; 0.8,0.1,0.1>$ \\
6 & Important (I) & $<(0.7,0.8,0.9,1.0) ; 0.8,0.2,0.2>$ \\
7 & Very Important (VI) & $<(1.0,1.0,1.0,1.0) ; 0.9,0.1,0.1>$ \\
\hline
\end{tabular}

Then, to obtain the aggregated opinions of consumers, we utilised TNWAA operator according to Equation (16). Opinions of postgraduate students participated in our survey were considered twice as important as undergraduate students' opinions. Afterwards, to get a crisp value the score function elaborated in Definition 5 and shown in Equation (10) has been applied to facilitate the comparisons of the resulted SVTNNs.

\subsection{Obtaining expert's judgements}

Forty-seven academic experts in the fields closely related to remanufacturing and consumer behaviour were contacted by invitation emails to take part in an on-line survey (Appendix B). Eight complete responses out of 47 had been received which were used in the analysis. The eight experts (see Table 7 for experts' profile) reviewed the outcome of the prior phase which was based on the consumers' opinions. That is to say, the seven best motivations which were resulted from consumers' opinions sent to the chosen experts then by utilising FD methodology the seven main motivations were assessed and prioritised.

Table 7. Academic experts' profiles

\begin{tabular}{ccccc}
\hline Expert & Expertise & Academic Position & Age & Country \\
\hline 1 & Remanufacturing & Associate Professor & 36 & USA \\
\hline 2 & Closed-loop Supply Chain & Professor & 49 & USA \\
\hline 3 & Remanufacturing & Professor & 35 & Germany \\
\hline 4 & Consumer Behaviour & Professor & 52 & France \\
\hline 5 & Remanufacturing & Professor & 59 & USA \\
\hline 6 & Closed-loop Supply Chain & Assistant Professor & 42 & USA \\
\hline 7 & Marketing & Associate Professor & 50 & France \\
\hline 8 & Consumer Behaviour & Assistant Professor & 34 & Sweden \\
\hline
\end{tabular}

The experts have proper knowledge and experience in the fields of remanufacturing, consumer behaviour, closed-loop supply chain and marketing with the average experience of 11 years in academia whose judgements can significantly improve the robustness of the results. The FD method applied for this purpose and the steps explained 
in the section 4.2 were shadowed. We assigned equal importance weights to each expert's opinions.

\section{Results}

The summarised data collected from the 104 potential consumers' opinions are represented in Table 8.

Table 8. Frequency Tables of Consumers' opinions on purchase motivations

\begin{tabular}{|c|c|c|c|c|c|c|c|}
\hline & & \multicolumn{2}{|c|}{ Price } & \multicolumn{2}{|c|}{$\begin{array}{l}\text { Environmental } \\
\text { Impact }\end{array}$} & \multicolumn{2}{|c|}{ Technology } \\
\hline \# & Answer & $\%$ & Count & $\%$ & Count & $\%$ & Count \\
\hline 1 & Very Unimportant & $2.9 \%$ & 3 & $7.7 \%$ & 8 & $1.0 \%$ & 1 \\
\hline 2 & Unimportant & $0.0 \%$ & o & $4.8 \%$ & 5 & $4.8 \%$ & 5 \\
\hline 3 & $\begin{array}{c}\text { Fairly } \\
\text { Unimportant }\end{array}$ & $2.9 \%$ & 3 & $10.6 \%$ & 11 & $10.6 \%$ & 11 \\
\hline 4 & Medium & $8.7 \%$ & 9 & $23.1 \%$ & 24 & $23.1 \%$ & 24 \\
\hline 5 & Fairly Important & $20.2 \%$ & 21 & $29.8 \%$ & 31 & $26.0 \%$ & 27 \\
\hline 6 & Important & $39.4 \%$ & 41 & $16.3 \%$ & 17 & $26.0 \%$ & 27 \\
\hline \multirow[t]{3}{*}{7} & Very Important & $26.0 \%$ & 27 & $7.7 \%$ & 8 & $8.7 \%$ & 9 \\
\hline & Total & $100 \%$ & 104 & $100 \%$ & 104 & $100 \%$ & 104 \\
\hline & & \multicolumn{2}{|c|}{$\begin{array}{l}\text { Value-added } \\
\text { Services }\end{array}$} & \multicolumn{2}{|c|}{ Warranty } & \multicolumn{2}{|c|}{ Quality } \\
\hline \# & Answer & $\%$ & Count & $\%$ & Count & $\%$ & Count \\
\hline 1 & Very Unimportant & $1.0 \%$ & 1 & $1.9 \%$ & 2 & $2.9 \%$ & 3 \\
\hline 2 & Unimportant & $3.8 \%$ & 4 & $1.9 \%$ & 2 & $0.0 \%$ & 0 \\
\hline 3 & $\begin{array}{c}\text { Fairly } \\
\text { Unimportant }\end{array}$ & $5.8 \%$ & 6 & $4.8 \%$ & 5 & $0.0 \%$ & 0 \\
\hline 4 & Medium & $17.3 \%$ & 18 & $12.5 \%$ & 13 & $2.9 \%$ & 3 \\
\hline 5 & Fairly Important & $31.7 \%$ & 33 & $9.6 \%$ & 10 & $11.5 \%$ & 12 \\
\hline 6 & Important & $23.1 \%$ & 24 & $26.9 \%$ & 28 & $27.9 \%$ & 29 \\
\hline \multirow[t]{3}{*}{7} & Very Important & $17.3 \%$ & 18 & $42.3 \%$ & 44 & $54.8 \%$ & 57 \\
\hline & Total & $100 \%$ & 104 & $100 \%$ & 104 & $100 \%$ & 104 \\
\hline & & \multicolumn{2}{|c|}{ Scarcity } & \multicolumn{2}{|c|}{ Unique Design } & \multicolumn{2}{|c|}{$\begin{array}{l}\text { Remanufacturer's } \\
\text { Reputation }\end{array}$} \\
\hline$\#$ & Answer & $\%$ & Count & $\%$ & Count & $\%$ & Count \\
\hline 1 & Very Unimportant & $3.8 \%$ & 4 & $2.9 \%$ & 3 & $1.0 \%$ & 1 \\
\hline 2 & Unimportant & $6.7 \%$ & 7 & $14.4 \%$ & 15 & $2.9 \%$ & 3 \\
\hline 3 & $\begin{array}{c}\text { Fairly } \\
\text { Unimportant }\end{array}$ & $7.7 \%$ & 8 & $19.2 \%$ & 20 & $7.7 \%$ & 8 \\
\hline 4 & Medium & $31.7 \%$ & 33 & $18.3 \%$ & 19 & $25.0 \%$ & 26 \\
\hline 5 & Fairly Important & $18.3 \%$ & 19 & $23.1 \%$ & 24 & $22.1 \%$ & 23 \\
\hline 6 & Important & $20.2 \%$ & 21 & $13.5 \%$ & 14 & $27.9 \%$ & 29 \\
\hline 7 & Very Important & $11.5 \%$ & 12 & $8.7 \%$ & 9 & $13.5 \%$ & 14 \\
\hline & Total & $100 \%$ & 104 & $100 \%$ & 104 & $100 \%$ & 104 \\
\hline
\end{tabular}

(C) 2018. This manuscript version is made available under the CC-BY-NC-ND 4.0 license http://creativecommons.org/licenses/by-nc-nd/4.0/ 22 


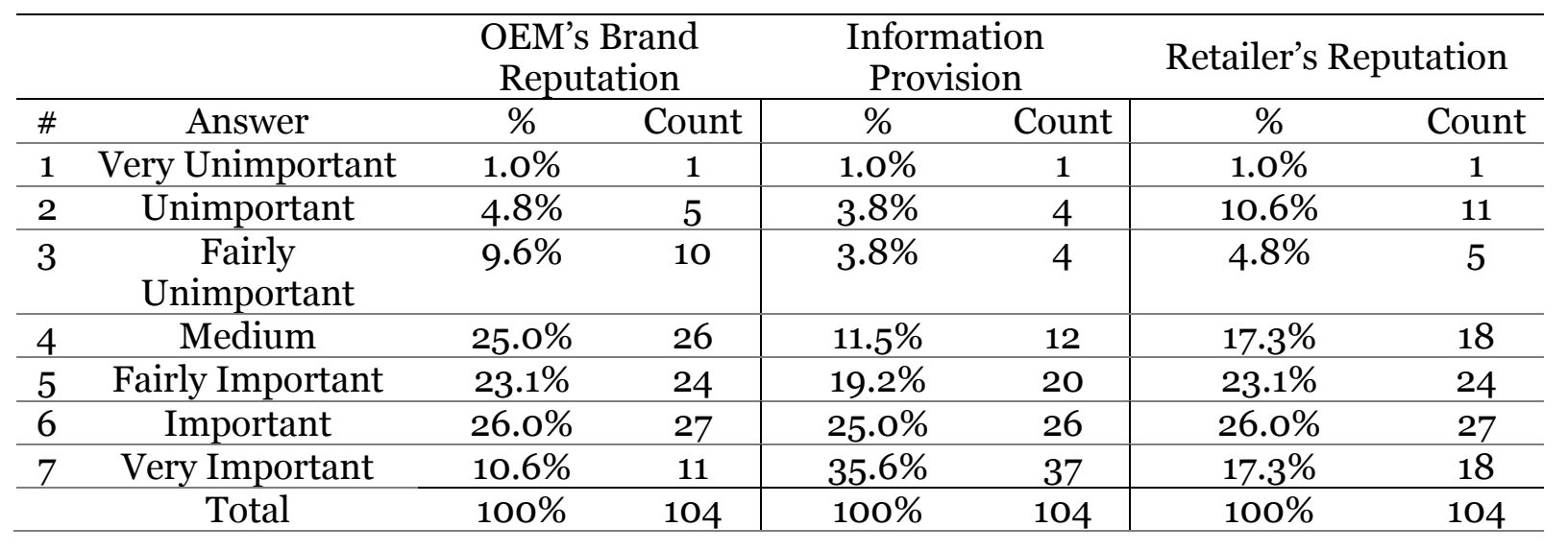

Based on phase two of our study and applying SVTNNs and TNWAA operator, the order of 12 motivations on the basis of consumers' opinions was reached (Table 9).

Table 9. Results of consumers' opinions

\begin{tabular}{ccc}
\hline Motivational Factor & Weight & Rank \\
\hline Quality & 0.78192 & 1 \\
Warranty & 0.73083 & 2 \\
Information Provision & 0.71785 & 3 \\
Price & 0.70031 & 4 \\
Value-added Services & 0.63785 & 5 \\
Remanufacturer's Reputation & 0.62028 & 6 \\
Retailer's Reputation & 0.61163 & 7 \\
OEM's Brand Reputation & 0.59764 & 8 \\
Technology & 0.58423 & 9 \\
Scarcity & 0.56894 & 10 \\
Environmental Impact & 0.53475 & 11 \\
Unique Design & 0.52020 & 12 \\
\hline
\end{tabular}

As it is obvious in Table 9, the obtained seven best motivations are quality, warranty, information provision, price, value-added services, remanufacturer's reputation and retailer's reputation respectively. Only seven factors among twelve were selected because of three reasons. Firstly, seven factors are more applicable for practitioners rather than numerous elements, particularly more than ten. Secondly, in the next phase in the FD method carrying out a large number of pair-wise comparisons would be confusing and time-consuming for experts to provide their judgements. Thirdly, it is suggested in the pair-wise comparisons literature that the maximum number for comparisons should be no more than seven factors (Saaty, 1980; Saaty and Ozdemir, 2003). Then, these seven motivations based on the experts' opinions utilising FD method (section 4.2) will be ranked to improve robustness and verify outcomes by incorporating both experts' and consumers' views. The achieved ranking derived from the experts' judgements appears in Table 10. The CR values for all experts' pair-wise comparisons were calculated and fixed and found to be less than 10\%. They are 9.01\%, 9.85\%, 8.59\%, 9.81\%, 9.92\%, 9.58\%, $8.23 \%$ and $9.71 \%$ respectively which reveals the reliability of the judgements.

(C) 2018. This manuscript version is made available under the CC-BY-NC-ND 4.0 license http://creativecommons.org/licenses/by-nc-nd/4.0/ 
Table 10. Results of experts' opinions

\begin{tabular}{ccc}
\hline Motivational Factor & Weight & Rank \\
\hline Price & 0.39459 & 1 \\
Warranty & 0.20734 & 2 \\
Remanufacturer's Reputation & 0.18286 & 3 \\
Quality & 0.17606 & 4 \\
Information Provision & 0.10652 & 5 \\
Retailer's Reputation & 0.08164 & 6 \\
Value-added Services & 0.05805 & 7 \\
\hline
\end{tabular}

It is quite apparent with reference to Table 10 that experts' judgements are relatively different to consumers' opinions other than warranty which lies at the second rank in both orders (see Table 11).

Findings indicate that price of the remanufactured bike is the most significant motivational factor in experts' opinions while quality is the critical motivator in consumers' perspective that lead them to buy a remanufactured bike. The second key motivation in both evaluations is warranty. On the bottom of the consumers' list (Table 9), are environmental impact and unique design which shows that albeit their expected importance, they do not seem to play a principal role in shaping the consumers' buying decision of a remanufactured bike in this study.

\section{Discussion}

Based on the analysis of the potential consumers' opinions, the seven critical motivational factors for buying a remanufactured bike obtained as quality, warranty, information provision, price, value-added services, remanufacturer's reputation, and retailer's reputation respectively. In our study, we tried to incorporate experts' opinions into our considerations in order to reach a more reliable order of motivations, thus, eight experts in the related fields provided their evaluations (Table 7). Aggregating opinions of experts and consumers is not a straightforward task as they see issues from different perspectives. However, it is attempted to reach a consensus on the motivational factors rankings. The combined ranking based on consumers' and experts' opinions are represented in Table 11. In the aggregated ranking, the average ranking was calculated putting more emphasis on the consumers opinions rather than experts which means averaged rankings closer to consumers' ranking were chosen.

Table 11. The combination of consumers' and experts' rankings

\begin{tabular}{cccc}
\hline Motivational Factor & $\begin{array}{c}\text { Consumers' } \\
\text { Ranking }\end{array}$ & $\begin{array}{c}\text { Experts' } \\
\text { Ranking }\end{array}$ & Combined Ranking \\
\hline Quality & 1 & 4 & 1 \\
\hline Warranty & 2 & 2 & 2 \\
\hline Information Provision & 3 & 5 & 4 \\
\hline
\end{tabular}

(C) 2018. This manuscript version is made available under the CC-BY-NC-ND 4.0 license http://creativecommons.org/licenses/by-nc-nd/4.0/ 


\begin{tabular}{clll}
\hline Price & 4 & 1 & 3 \\
\hline Value-added Services & 5 & 7 & 6 \\
\hline Remanufacturer's Reputation & 6 & 3 & 5 \\
\hline Retailer's Reputation & 7 & 6 & 7 \\
\hline
\end{tabular}

This outcome confirms the result of prior studies that have noted quality and price as two pivotal factors affecting purchase intention (PI) of consumers for remanufactured products (Agrawal et al., 2015; Atasu et al., 2010; Guide Jr and Van Wassenhove, 2001; Jiménez-Parra et al., 2014). For instance, quality as one of the important factors which was already indicated by Hazen et al. (2017a) that consumer perception of the remanufactured products quality is one of the chief reasons for remanufacturing's failure to achieve its potential. Abbey et al. (2017) found that consumers hold overriding concern about the quality of remanufactured goods. Abbey et al. (2015) identified quality perceptions as significant drivers of increased demand for remanufactured product which was also obtained in our study. Ma et al. (2017) identified that perceived quality has a positive effect on remanufactured electronic products purchase attitude. Price was the third identified potential motivator for Abbey et al. (2015) as well. The study of JiménezParra et al. (2014) revealed that motivations such as price and environmental issues play a key positive role in the purchase intention of remanufactured laptops while technological aspects have a negative impact on consumers' motivation. In our findings, also Technology factor was not listed among the seven significant motivations as it ranked $9^{\text {th }}$ in consumers' opinion (Table 9). Giutini and Gaudette (2003) indicated the price of remanufactured products is nearly $30-40 \%$ lower than newly manufactured counterparts which can obviously act as a proper motivator for potential consumers.

Warranty was revealed in both consumers' and experts' opinions as the second most significant factor so it stood at the second priority in the final ranking. In the definition of a remanufactured product (section 1.1), it is indicated that remanufactured products reach the same warranty level or even better warranty compared to new products. Thus, warranty would not be normally a great deal of concern but remanufacturers should pay more attention to this element as it was recognised by both consumers and experts as the second most crucial motivator. In comparison between warranty and price, Subramanian and Subramanyam (2012) found that stronger warranties are not remarkably related to higher prices paid for remanufactured products.

Information provision was the fourth identified purchase motivator in our findings. It can be related to perceived knowledge indicated in Ma et al. (2017) as a positive factor on purchase attitude of a remanufactured electronic product. Perceived knowledge is about general knowledge about remanufacturing which implies the more consumers know about remanufactured products the more likely they will buy them. In our study, information provision is about detailed information about the specific remanufactured bike such as its age, possible damages, proportion of remanufactured components, results of performance tests, use history, use intensity (average use hours per day) and reason of discarding. The provided information can also correspond with the general perceived knowledge of the remanufactured product. The influence of information asymmetry on the markets' functions was first discussed in Akerlof (1970). The problem is particularly 
highlighted in on-line markets such as eBay because potential consumers have no opportunity to check the product before buying or they do not have enough information about product usage background. The information provision factor appears to be connected to quality as well as value-added services that should be taken into consideration. The value-added services identified as the $6^{\text {th }}$ most important factor affecting buying intention of consumers.

Abbey et al. (2015) showed that branding effect or remanufacturer's reputation positively impacts the quality perceptions of consumers for new products which is not necessarily the case for remanufactured products. This issue of how and why consumers dissociate the positive benefits of the original brand from the remanufactured product has remained an open, unsolved challenge. However, our study revealed that this brand equity or remanufacturer's reputation plays an important role to encourage the purchase of a remanufactured bike as it was $5^{\text {th }}$ among the seven critical motivators.

At the bottom of our seven-factor list is retailer's reputation. In Van Weelden et al. (2016) it was identified that some interviewed potential consumers of refurbished/remanufactured phones were identified as uninterested to take extra effort to go to a special retailer to purchase the remanufactured product. It was also declared that the remanufactured phones were not offered by established retail channels which made it hard to take remanufactured products into consideration. In our findings, retailer's reputation was found as a relatively less interesting factor among other motivational factors. However, being comparatively less important does not necessarily mean that it cannot have an impact on purchase intention. If remanufactured products can be offered in established popular retail channels or being conveniently accessible by consumers in special retailers they can positively encourage purchase, even if not as effectively as quality, warranty or price.

The final noteworthy point is that environmental impact has not been regarded as one of the seven most significant motivators for buying a remanufactured bike in our study as it was ranked $11^{\text {th }}$ out of 12 factors (Table 9). This finding was in line with the study of Abbey et al. (2015) where the researchers identified lack of green consumer interest in remanufactured products. However, in much of the remanufacturing literature, environmental impact or green benefits of remanufacturing are presumed to be a key motivator to encourage the purchase of remanufactured products by customers (Abbey et al., 2015).

\section{Conclusions}

Environmental issues caused by solid waste of manufactured goods have resulted in stricter legislation as well as consumer awareness. The environmental awareness of consumers generally provided a fresh market opportunity in various businesses to offer environmentally friendly or green products (even though, the extent of the influence of customers' green interest on their PI is debatable). Moreover, generating new economic opportunities such as skilled jobs made firms implement end-of-life strategies like 
remanufacturing. Customers' perceptions on remanufactured products as one of the CLSC factors significantly impact demand of remanufactured products. On the other hand, it is also important for remanufacturing firms to know which factors lead potential customers to purchase a specific remanufactured product to adjust their operations accordingly and maximise their selling volume and profitability.

Literature suggests studies that explored the demand side of the remanufacturing supply chain are handful. Additionally, understanding factors impacting on consumers acceptance of remanufactured products has been recognised as one of the key drivers of improving sustainability and profitability of the remanufacturing supply chain. Consequently, in this study, we attempted to address this significant topic by contribution to the demand side of the CLSC. One of the aspects of demand side would be consumer purchasing behaviour of remanufactured products like consumers' motivations to buy remanufactured bikes that was explored in our study. Main consumers' motivations to buy a remanufactured bike were analysed by collecting data from students based in Norwich, UK utilising literature survey as well as experts' opinions. The notion of incorporating consumers' opinions and experts' judgements by applying appropriate methods was utilised in this study.

For this purpose, twelve main consumers' motivations which lead potential consumers to purchase a remanufactured bike were identified. Then, SVTNN and the TNWAA operator were employed to capture the uncertainty of consumers' subjective judgements to obtain 7 motivations out of 12 initial motivations which had already resulted from the literature survey. We received 104 questionnaires complete and suitable for further analysis. The resulted seven best motivations were quality, warranty, information provision, price, value-added services, remanufacturer's reputation, and retailer's reputation respectively. Then, the seven motivations were ranked according to the eight experts' judgements utilising the FD method. Consequently, in a combined ranking, the most critical consumers' motivations revealed as quality, warranty, price, information provision, remanufacturer's reputation, value-added services and retailer's reputation respectively. In fact, experts' judgements added more insight into the consumers' opinions to obtain the final ranking of motivators.

The contributions of this research are threefold. Firstly, it addressed a gap in the remanufacturing and CLSC literature by exploring the demand side of the supply chain and main motivations of consumers to buy a remanufactured bike. Secondly, application of a novel methodological approach was proposed in the FD method by introducing averaging viewpoint in the formation of TFNs by applying the arithmetic-geometricharmonic mean inequality concept. Thirdly, the SVNS theory and the SVTNN were applied in a practical case in remanufacturing and consumer behaviour areas.

The results of this research can be applied in further investigation of PI. The identified motivations would be valuable tools for firms in the current competitive market because they can effectively assist companies in developing efficient marketing strategies. This study delivers a fresh insight into the demand side of remanufacturing supply chain literature which merits further exploration particularly by applying advanced quantitative methods.

(C) 2018. This manuscript version is made available under the CC-BY-NC-ND 4.0 license http://creativecommons.org/licenses/by-nc-nd/4.0/ 
In future studies, hybrid non-deterministic methods such as NS theory and other multiple attribute decision making (MADM) methods can be applied and offer a more realistic perspective on the remanufacturing and CLSC issues by capturing uncertainty of DMs' subjective judgements. Furthermore, not all motivators are independent - for example quality and value-added services can be closely interconnected - methods like DEMATEL or ISM can be useful in leading to more robust prioritisation. The motivators which are inherently positive features encouraging consumers purchasing remanufactured bikes were investigated in this study. Taking into account the barriers or negative criteria which lead consumers not buying remanufactured products or encourage them to regard those products unappealing can be investigated in future research. In this research, the importance weights of all experts considered as equal which can also be considered as different fuzzy or grey numbers to efficiently capture the weights of the judgements based on the experience and knowledge of experts. Moreover, more participants in future studies (either consumers or experts) can be recruited or practitioners can also be involved in the research to provide more reliable results.

\section{References}

Abbey, J. D., Kleber, R., Souza, G. C., \& Voigt, G. (2017). The Role of Perceived Quality Risk in Pricing Remanufactured Products. Production and Operations Management, 26(1), 100115 .

Abbey, J. D., Meloy, M. G., Blackburn, J., \& Guide, V. D. R. (2015). Consumer markets for remanufactured and refurbished products. California Management Review, 57(4), 26-42.

Agrawal, V. V, Atasu, A., \& van Ittersum, K. (2015). Remanufacturing, Third-Party Competition, and Consumers' Perceived Value of New Products. Management Science, 61(1), 1-26.

Aguarón, J., Escobar, M. T., \& Moreno-Jiménez, J. M. (2016). The precise consistency consensus matrix in a local AHP-group decision making context. Annals of Operations Research, 245(1-2), 245-259.

Aguaron, J., \& Moreno-Jiménez, J. M. (2003). The geometric consistency index: Approximated thresholds. European Journal of Operational Research, 147(1), 137-145.

Akerlof, G. A. (1970). The market for" lemons": Quality uncertainty and the market mechanism. The Quarterly Journal of Economics, 84(3), 488-500.

Alqahtani, A. Y., \& Gupta, S. M. (2017). Warranty as a marketing strategy for remanufactured products. Journal of Cleaner Production, 161, 1294-1307.

Atanassov, K. T. (1986). Intuitionistic Fuzzy Sets. Fuzzy Sets and Systems, 20, 87-96. 
Atasu, A., Guide, V. D. R., \& Wassenhove, L. N. Van. (2010). So what if remanufacturing cannibalizes my new product sales? California Management Review, 52(2), 56-76.

Atasu, A., Guide, V. D. R., \& Van Wassenhove, L. N. (2008a). Product Reuse Economics in ClosedLoop Supply Chain Research. Production and Operations Management, 17(5), 483-496.

Atasu, A., Sarvary, M., \& Van Wassenhove, L. N. (2008b). Remanufacturing as a Marketing Strategy. Management Science, 54(10), 1731-1746.

Ayres, R., Ferrer, G., \& Van Leynseele, T. (1997). Eco-efficiency, asset recovery and remanufacturing. European Management Journal, 15(5), 557-574.

Bhosale, V. A., \& Kant, R. (2016). An integrated ISM fuzzy MICMAC approach for modelling the supply chain knowledge flow enablers. International Journal of Production Research, 7543(August), 1-26.

Bulmus, S. C., Zhu, S. X., \& Teunter, R. (2014). Competition for cores in remanufacturing. European Journal of Operational Research, 233(1), 105-113.

Camacho Otero, J., Pettersen, I. N., \& Boks, C. (2017). Consumer and user acceptance in the circular economy: what are researchers missing? PLATE Conference, Delft University of Technology, 8-10 November.

Centre for Remanufacturing \& Reuse (CRR) Available at: www.remanufacturing.org.uk/reasonsto-remanufacture.php Accessed on: 29 November 2016.

Chapman, A., Bartlett, C., McGill, I., Parker, D., \& Walsh, B. (2010). Remanufacturing in the UK. Resource Recovery Forum.

Chen, H., Liu, N., \& He, Y. (2016). Remanufacturing of electronic products in bonded port area across home and foreign markets. The International Journal of Logistics Management. 27(2), 309-334.

Chen, J., \& Ye, J. (2016). A Projection Model of Neutrosophic Numbers for Multiple Attribute Decision Making of Clay-Brick Selection. Neutrosophic Sets \& Systems, 12, 139-142.

Cui, L., Wu, K. J., \& Tseng, M. L. (2017). Selecting a remanufacturing quality strategy based on consumer preferences. Journal of Cleaner Production, 161, 1308-1316.

Debo, L. G., Toktay, L. B., \& Van Wassenhove, L. N. (2005). Market Segmentation and Product Technology Selection for Remanufacturable Products. Management Science, 51(8), 11931205 .

Deli, I., \& Şubaş, Y. (2014). Single valued neutrosophic numbers and their applications to multicriteria decision making problem.

European Commission. (2009). Europeans' attitudes towards the issue of sustainable consumption and production. Flash Eurobarometer 256, (July 2009), 86.

(C) 2018. This manuscript version is made available under the CC-BY-NC-ND 4.0 license http://creativecommons.org/licenses/by-nc-nd/4.0/ 
Frota Neto, J. Q., Bloemhof, J., \& Corbett, C. (2016). Market prices of remanufactured, used and new items: Evidence from eBay. International Journal of Production Economics, 171, 371380 .

Ferguson, M., \& Toktay, L. B. (2006). The Effect of Competition on Recovery Strategies. Production and Operations Management, 15(3), 351-368.

Giutini, R., \& Gaudette, K. (2003). Remanufacturing: The next great opportunity for boosting US productivity. Business Horizons, 46(6), 41-48.

Golden, B.L., Harker, P.T., \& Wasil, E.E. (1989). The Analytic Hierarchy Process: Applications and Studies, Springer-Verlag, Berlin.

Govindan, K., Khodaverdi, R., \& Vafadarnikjoo, A. (2015). Intuitionistic fuzzy based dematel method for developing green practices and performances in a green supply chain. Expert Systems with Applications, 42(20), 7207-7220.

Govindan, K., Madan Shankar, K., \& Kannan, D. (2016a). Application of fuzzy analytic network process for barrier evaluation in automotive parts remanufacturing towards cleaner production - a study in an Indian scenario. Journal of Cleaner Production, 114, 199-213.

Govindan, K., Khodaverdi, R., \& Vafadarnikjoo, A. (2016b). A grey DEMATEL approach to develop third-party logistics provider selection criteria. Industrial Management \& Data Systems, 116(4), 690-722.

Guide, J. V. D. R., \& Li, J. (2010). The potential for Cannibalization of new products sales by remanufactured products. Decision Sciences, 41(3), 547-572.

Guide Jr, V. D. R., \& Van Wassenhove, L. N. (2001). Managing Product Returns for Remanufacturing. Production \& Operations Management, 1O(2), 142-155.

Gullstrand Edbring, E., Lehner, M., \& Mont, O. (2016). Exploring consumer attitudes to alternative models of consumption: motivations and barriers. Journal of Cleaner Production, 123, 5-15.

Hamilton, S. F., \& Zilberman, D. (2006). Green markets, eco-certification, and equilibrium fraud. Journal of Environmental Economics and Management, 52(3), 627-644.

Hatcher, G. D., Ijomah, W. L., \& Windmill, J. F. C. (2011). Design for remanufacture: a literature review and future research needs. Journal of Cleaner Production, 19(17), 2004-2014.

Hayaty, M., Mohammadi, M. R. T., Rezaei, A., \& Shayestehfar, M. R. (2014). Risk Assessment and Ranking of Metals Using FDAHP and TOPSIS. Mine Water and the Environment, 33(2), 157-164.

Hazen, B. T., Overstreet, R. E., Jones-Farmer, L. A., \& Field, H. S. (2012). The role of ambiguity tolerance in consumer perception of remanufactured products. International Journal of Production Economics, 135(2), 781-790.

(C) 2018. This manuscript version is made available under the CC-BY-NC-ND 4.0 license http://creativecommons.org/licenses/by-nc-nd/4.0/ 
Hazen, B. T., Boone, C. A., Wang, Y., \& Khor, K. S. (2017a). Perceived quality of remanufactured products: construct and measure development. Journal of Cleaner Production, 142, 716726.

Hazen, B. T., Mollenkopf, D. A., \& Wang, Y. (2017b). Remanufacturing for the circular economy: an examination of consumer switching behavior. Business Strategy and the Environment, 26(4), 451-464.

Ijomah, W. L., McMahon, C. A., Hammond, G. P., \& Newman, S. T. (2007). Development of design for remanufacturing guidelines to support sustainable manufacturing. Robotics and Computer-Integrated Manufacturing, 23(6), 712-719.

Ishizaka, A., \& Lusti, M. (2004). An expert module to improve the consistency of AHP matrices. International Transactions in Operational Research, 11(1), 97-105.

Jackson, T. (2005). Motivating sustainable consumption. Sustainable Development Research Network.

Ji, P., Wang, J., \& Zhang, H. (2016). Frank prioritized Bonferroni mean operator with singlevalued neutrosophic sets and its application in selecting third-party logistics providers. Neural Computing and Applications. http://doi.org/10.1007/s00521-016-2660-6

Jia, J., Xu, S. H., \& Guide, V. D. R. (2016). Addressing Supply-Demand Imbalance: Designing Efficient Remanufacturing Strategies. Production and Operations Management, 25(11), $1958-1967$.

Jiménez-Parra, B., Rubio, S., \& Vicente-Molina, M.-A. (2014). Key drivers in the behavior of potential consumers of remanufactured products: a study on laptops in Spain. Journal of Cleaner Production, 85, 488-496.

Jiménez-Parra, B., Rubio-Lacoba, S., \& Vicente-Molina, A. (2012, July). An approximation to the remanufactured electrical and electronic equipment consumer. In 6th International Conference on Industrial Engineering and Industrial Management (pp. 433-440).

Khor, K. S., \& Hazen, B. T. (2016). Remanufactured products purchase intentions and behaviour: Evidence from Malaysia. International Journal of Production Research, 7543(June), 1-14.

Kumar, A., Chinnam, R. B., \& Murat, A. (2017). Hazard rate models for core return modeling in auto parts remanufacturing. International Journal of Production Economics, 183, 354-361.

Kwong, C. K., \& Bai, H. (2002). A fuzzy AHP approach to the determination of importance weights of customer requirements in quality function deployment. Journal of Intelligent Manufacturing, 13(5), 367-377.

Lai, Y.J., \& Hwang, C.L. (1995). Fuzzy Mathematical Programming: Methods and Applications. Springer-Verlag, New York.

Lee, K.H. (2005). First Course on Fuzzy Theory and Applications. Springer-Verlag, Berlin

(C) 2018. This manuscript version is made available under the CC-BY-NC-ND 4.0 license http://creativecommons.org/licenses/by-nc-nd/4.0/ 
Leung, L. C., \& Cao, D. (2000). On consistency and ranking of alternatives in fuzzy AHP. European Journal of Operational Research, 124, 102-113.

Li, W., Wu, H., Jin, M., \& Lai, M. (2017a). Two-stage Remanufacturing Decision Makings Considering Product Life Cycle and Consumer Perception. Journal of Cleaner Production, 161, 581-590.

Li, Y. Y., Zhang, H. Y., \& Wang, J. Q. (2017b). Linguistic neutrosophic sets and their application in multicriteria decision-making problems. International Journal for Uncertainty Quantification, 7(2), 135-154.

Linares, P., Lumbreras, S., Santamaría, A., \& Veiga, A. (2016). How relevant is the lack of reciprocity in pairwise comparisons? An experiment with AHP. Annals of Operations Research, 245(1-2), 227-244.

Liu, Y., \& Chen, C. (2007). A new approach for application of rock mass classification on rock slope stability assessment. Engineering Geology, 89, 129-143.

Ma, L., Su, X., Wang, C., Lin, K., \& Lin, M. (2017, June). Consumers' intention to purchase remanufactured electronic products: An empirical study in China. In Service Systems and Service Management (ICSSSM), 2017 International Conference on (pp. 1-6). IEEE.

Majumder, P., \& Groenevelt, H. (2001). Competition in remanufacturing. Production and Operations Management, 10(2), 125-141.

Matsumoto, M. ., Yang, S. ., Martinsen, K. ., \& Kainuma, Y. . (2016). Trends and research challenges in remanufacturing. International Journal of Precision Engineering and Manufacturing - Green Technology, 3(1), 129-142.

Michaud, C., \& Llerena, D. (2011). Green consumer behaviour: An experimental analysis of willingness to pay for remanufactured products. Business Strategy and the Environment, 2O(6), 408-420.

Mugge, R., Jockin, B., \& Bocken, N. (2017). How to sell refurbished smartphones? An investigation of different customer groups and appropriate incentives. Journal of Cleaner Production, 147, 284-296.

Mutha, A., Bansal, S., \& Guide, V. D. R. (2016). Managing Demand Uncertainty through Core Acquisition in Remanufacturing. Production and Operations Management, 25(8), 14491464 .

Örsdemir, A., Kemahlioğlu-Ziya, E., \& Parlaktürk, A. K. (2014). Competitive quality choice and remanufacturing. Production and Operations Management, 23(1), 48-64.

Ovchinnikov, A. (2011). Revenue and cost management for remanufactured products. Production and Operations Management, 2O(6), 824-840.

Parker, D. (2004). Remanufacturing in the UK. Oakdene Hollins

(C) 2018. This manuscript version is made available under the CC-BY-NC-ND 4.0 license http://creativecommons.org/licenses/by-nc-nd/4.0/ 
Parker, D., \& Butler, P. (2007). An introduction to remanufacturing. Oakdene Hollins Ltd: Aylesbury.

Parker, D., Riley, K., Robinson, S., Symington, H., Tewson, J., Jansson, K., ... Peck, D. (2015). Remanufacturing Market Study. European Remanufacturing Network.

Peng, H., Zhang, H., \& Wang, J. (2016). Probability multi-valued neutrosophic sets and its application in multi-criteria group decision-making problems. Neural Computing and Applications. https://doi.org/10.1007/s00521-016-2702-0

Pereira, V., \& Costa, H. G. (2015). Nonlinear programming applied to the reduction of inconsistency in the AHP method. Annals of Operations Research, 229(1), 635-655.

Peters, K. (2016). Methodological issues in life cycle assessment for remanufactured products: a critical review of existing studies and an illustrative case study. Journal of Cleaner Production, 126, 21-37.

Pokharel, S., \& Liang, Y. (2012). A model to evaluate acquisition price and quantity of used products for remanufacturing. International Journal of Production Economics, 138(1), 170176.

Prahinski, C., \& Kocabasoglu, C. (2006). Empirical research opportunities in reverse supply chains. Omega, 34(6), 519-532.

Qiang, Q. (Patrick). (2015). The closed-loop supply chain network with competition and design for remanufactureability. Journal of Cleaner Production, 105, 348-356.

Rivieccio, U. (2008). Neutrosophic logics: Prospects and problems. Fuzzy Sets and Systems, 159(14), 1860-1868.

Rubio, S., Chamorro, A., \& Miranda, F. J. (2008). Characteristics of the research on reverse logistics (1995-2005). International Journal of Production Research, 46(4), 1099-1120.

Saaty, T.L. (1980). The analytic hierarchy process, McGraw-Hill, New York.

Saaty, T.L. (1994). Fundamentals of Decision Making, RSW Publications.

Saaty, T. L., \& Ozdemir, M. S. (2003). Why the magic number seven plus or minus two. Mathematical and Computer Modelling, 38(3), 233-244.

Sahin, R., \& Yigider, M. (2014). A Multi-criteria neutrosophic group decision making method based TOPSIS for supplier selection. arXiv preprint arXiv:1412.5077.

Sharma, V., Garg, S. K., \& Sharma, P. B. (2016). Identification of major drivers and roadblocks for remanufacturing in India. Journal of Cleaner Production, 112, 1882-1892.

Smarandache, F. (1999). A unifying field in logics: neutrosophic logic. Neutrosophy, neutrosophic set, probability. American Research Press, Rehoboth

(C) 2018. This manuscript version is made available under the CC-BY-NC-ND 4.0 license http://creativecommons.org/licenses/by-nc-nd/4.0/ 
Smarandache, F. (1998). Neutrosophy: Neutrosophic probability, set, and logic. American Research Press, Rehoboth

Subramoniam, R., Huisingh, D., \& Chinnam, R. B. (2009). Remanufacturing for the automotive aftermarket-strategic factors: literature review and future research needs. Journal of Cleaner Production, 17(13), 1163-1174.

Subramanian, R., \& Subramanyam, R. (2012). Key factors in the market for remanufactured products. Manufacturing and Service Operations Management, 14(2), 315-326.

Thierry, M., Salomon, M., Nunen, J. Van, \& Wassenhove, L. Van. (1995). Strategic issues in product recovery management. California Management Review, 37(2), 114-135.

Thorn, B.K., Rogerson, P., (2002). Take it back. IIE Solutions 34 (4), 34-40.

Tian, Z. peng, Wang, J., Wang, J. qiang, \& Zhang, H. yu. (2017). Simplified Neutrosophic Linguistic Multi-criteria Group Decision-Making Approach to Green Product Development. Group Decision and Negotiation, 26(3), 597-627.

Vafadarnikjoo, A., Mobin, M., Allahi, S., \& Rastegari, A. (2015). A hybrid approach of intuitionistic fuzzy set theory and dematel method to prioritize selection Criteria of bank branches locations. In International Annual Conference of the American Society for Engineering Management ASEM.10 $0^{\text {th }}$ October, Indianapolis, Indiana, USA.

Vafadarnikjoo, A. (2014). Corrigendum to "Using fuzzy DEMATEL to evaluate the green supply chain management practices"[J. Clean. Prod. 40 (2013) 32-39]. Journal of Cleaner Production, 82, 232.

Van Weelden, E., Mugge, R., \& Bakker, C. (2016). Paving the way towards circular consumption: exploring consumer acceptance of refurbished mobile phones in the Dutch market. Journal of Cleaner Production, 113, 743-754.

Wang, H., Smarandache, F., Zhang, Y.-Q., \& Sunderraman, R. (2010). Single valued neutrosophic sets. Rev Air Force Acad, 17(1), 10-14.

Wang, Y., \& Hazen, B. T. (2016). Consumer product knowledge and intention to purchase remanufactured products. International Journal of Production Economics, 181, 460-469.

Wang, Y., Huscroft, J. R., Hazen, B. T., \& Zhang, M. (2016). Green information, green certification and consumer perceptions of remanufctured automobile parts. Resources, Conservation and Recycling.

Wang, Y., Wiegerinck, V., Krikke, H., \& Zhang, H. (2013). Understanding the purchase intention towards remanufactured product in closed-loop supply chains: An empirical study in China. International Journal of Physical Distribution \& Logistics Management, 43(10), 866-888. 
Watson, M. (2008). A Review of the Literature and Research on Public Attitudes, Perceptions and Behaviour Relating to Remanufactured, Repaired and Reused Products. Centre for Remanufacturing \& Reuse, (March), 1-26.

Wei, S., Cheng, D., Sundin, E., \& Tang, O. (2015). Motives and barriers of the remanufacturing industry in China. Journal of Cleaner Production, 94, 340-351.

Wu, C.-H., \& Wu, H.-H. (2016). Competitive remanufacturing strategy and take-back decision with OEM remanufacturing. Computers \& Industrial Engineering, 98, 149-163.

Xia, D.-F., Xu, S.-L., \& Qi, F. (1999). A proof of the arithmetic mean-geometric mean-harmonic mean inequalities. RGMIA Research Report Collection, 2(1), 85-87.

Xia, X., Govindan, K., \& Zhu, Q. (2015). Analyzing internal barriers for automotive parts remanufacturers in China using grey-DEMATEL approach. Journal of Cleaner Production, $87,811-825$.

Xiong, Y., Zhao, Q., \& Zhou, Y. (2016). Manufacturer-remanufacturing vs supplierremanufacturing in a closed-loop supply chain. International Journal of Production Economics, 176, 21-28.

Ye, J. (2015). Single-valued neutrosophic similarity measures based on cotangent function and their application in the fault diagnosis of steam turbine. Soft Computing, 1-9.

Ye, J. (2017). Some weighted aggregation operators of trapezoidal neutrosophic numbers and their multiple attribute decision making method, Informatica, inpress.

Ye, J., \& Smarandache, F. (2016). Similarity Measure of Refined Single-Valued Neutrosophic Sets and Its Multicriteria Decision Making Method. Neutrosophic Sets \& Systems, 12, 41-44.

Zadeh, L. A. (1965). Fuzzy sets. Information and Control, 8(3), 338-353.

Zafirakis, D., Elmasides, C., Sauer, D. U., Leuthold, M., Merei, G., Kaldellis, J. K., ... \& Chalvatzis, K. J. (2014). The multiple role of energy storage in the industrial sector: Evidence from a Greek industrial facility. Energy Procedia, 46, 178-185.

Zavadskas, E. K., Baušys, R., \& Lazauskas, M. (2015). Sustainable assessment of alternative sites for the construction of a waste incineration plant by applying WASPAS method with singlevalued neutrosophic set. Sustainability (Switzerland), 7(12), 15923-15936.

Zavadskas, E. K., Baušys, R., Stanujkic, D., \& Magdalinovic-Kalinovic, M. (2016). Selection of lead-zinc flotation circuit design by applying WASPAS method with single-valued neutrosophic set. Acta Montanistica Slovaca, 21(2), 85-92.

Zhang, J.-H., Yang, B., \& Chen, M. (2017). Challenges of the development for automotive parts remanufacturing in China. Journal of Cleaner Production, 140, 1087-1094.

(C) 2018. This manuscript version is made available under the CC-BY-NC-ND 4.0 license http://creativecommons.org/licenses/by-nc-nd/4.0/ 


\section{Appendix A: Consumers' opinions survey}

Imagine you are looking for a bike to buy and come across a nice one in a retailer which is for sale but it is labelled as a remanufactured bike although it looks like a new one! What would you do then? Would you buy it or look for a newly manufactured counterpart? Here, we want to know which factors would possibly drive or encourage you as a potential customer to buy a remanufactured bike. We mean by bike the typical hybrid bike (everyday bike) which is the most common kind of bikes that most people consider comfortable.

Please choose a number from the following scale ( 1 to 7 ) which shows the extent you agree that a factor is important as a driver or inspiration to motivate you to buy a remanufactured bike:

\begin{tabular}{cc}
\hline Numerical Scale & Verbal Scale \\
\hline 1 & Very Unimportant (VU) \\
\hline 2 & Unimportant (U) \\
\hline 3 & Fairly Unimportant (FU) \\
\hline 4 & Medium (M) \\
\hline 5 & Fairly Important (FI) \\
\hline 6 & Important (I) \\
\hline 7 & Very Important (VI) \\
\hline
\end{tabular}

1. Price: To what extent price of a remanufactured bike can be regarded as a motivation to lead you to purchase it?

Answer (1 to 7):

2. Environmental Impact: To what extent environmental impact of a remanufactured bike can be regarded as a motivation to lead you to purchase it?

Answer (1 to 7):

3. Technology: To what extent technology of a remanufactured bike can be regarded as a motivation to lead you to purchase it?

Answer (1 to 7): 
4. Value-added Services: To what extent value-added services such as trying out chance, free shipping and reward levels of a remanufactured bike can be regarded as a motivation to lead you to purchase it?

Answer (1 to 7):

5. Warranty: To what extent warranty of a remanufactured bike can be regarded as a motivation to lead you to purchase it?

Answer (1 to 7):

6. Quality: To what extent quality such as performance characteristics and perceived functional risk of a remanufactured bike can be regarded as a motivation to lead you to purchase it?

Answer (1 to 7):

7. Scarcity: To what extent scarcity or non-availability of new counterparts of a remanufactured bike can be regarded as a motivation to lead you to purchase it?

Answer (1 to 7):

8. Unique Design: To what extent unique design of a remanufactured bike can be regarded as a motivation to lead you to purchase it?

Answer (1 to 7):

9. Remanufacturer's Reputation: To what extent remanufacturer's reputation (For example, it is recognised as an approved remanufacturer by $\mathrm{OEM}^{1}$ ) of a remanufactured bike can be regarded as a motivation to lead you to purchase it?

Answer (1 to 7):

10. OEM's Brand Reputation: To what extent OEM's brand reputation of a remanufactured bike can be regarded as a motivation to lead you to purchase it?

${ }^{1}$ OEM=Original Equipment Manufacturer

(C) 2018. This manuscript version is made available under the CC-BY-NC-ND 4.0 license http://creativecommons.org/licenses/by-nc-nd/4.0/ 
Answer (1 to 7):

11. Information Provision: To what extent information provision of a remanufactured bike can be regarded as a motivation to lead you to purchase it? Information about a remanufactured bike's status includes information like its age, possible damages, proportion of remanufactured components and results of performance tests. Also, information about the use history could give insight on how the bike was used for example use intensity (average hours per day), reason of discarding and so on.

Answer (1 to 7):

12. Retailer's Reputation: To what extent retailer's reputation of a remanufactured bike can be regarded as a motivation to lead you to purchase it?

Answer (1 to 7): 


\section{Appendix B: Experts' Judgements survey}

Please choose a number from the following scale (1 to 9) which shows the importance degree of each motivation in comparison with other motivations.

\begin{tabular}{cc}
\hline Numerical Scale & Verbal Scale \\
\hline 1 & Equal Importance \\
\hline 2 & Weak Importance \\
\hline 3 & Moderate Importance \\
\hline 4 & Moderate Plus Importance \\
\hline 5 & Strong Importance \\
\hline 6 & Strong Plus Importance \\
\hline 7 & Very Strong Importance \\
\hline 8 & Very Very Strong Importance \\
\hline 9 & Extreme Importance \\
\hline
\end{tabular}

The followings pairwise comparisons are given as examples to illustrate how to give your opinion:

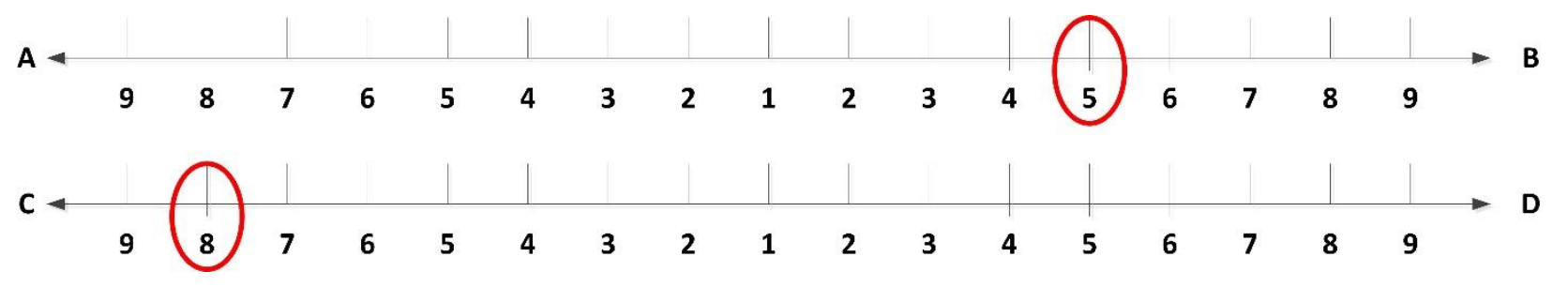

Comparing $A$ to $B$, the expert chose 5 on the right side (Side $B$ ) which means $B$ gets Strong Importance or the expert strongly favoured $B$ over $A$.

Comparing $C$ to $D$, the expert favoured $C$ over $D$ and assigned number 8 which means Very Very Strong Importance.

The questionnaire includes 21 questions like the examples above comparing 7 motivational factors: quality, warranty, information provision, price, value-added services, remanufacturer's reputation, retailer's reputation 